\title{
GLACIAL LANDFORMS AS GEODIVERSITY RESOURCES FOR GEOTOURISM IN TIERRA DEL FUEGO, ARGENTINA
}

\author{
Andrea Coronato ${ }^{1,2}$, Soledad Schwarz ${ }^{3}{ }^{3}$, Flavia Flores Barrera $\oplus^{3}$ \\ ${ }^{1}$ Centro Austral de Investigaciones Científicas (CADIC-CONICET), Ushuaia, Argentina \\ ${ }^{2}$ Instituto de Ciencias Polares, Ambiente y Recursos Naturales, Universidad Nacional de Tierra del Fuego, \\ Antártida e Islas del Atlántico Sur, Ushuaia, Argentina \\ ${ }^{3}$ Instituto de Desarrollo Económico e Innovación, Universidad Nacional de Tierra del Fuego, Antártida e Islas \\ del Atlántico Sur, Ushuaia, Argentina
}

Manuscript received: April 29, 2021

Revised version: September 12, 2021

Coronato A., Schwarz S., Flores Barrera F., 2022. Glacial landforms as geodiversity resources for geotourism in Tierra del Fuego, Argentina. Quaestiones Geographicae 41(1), Bogucki Wydawnictwo Naukowe, Poznań, pp. 5-24. 12 figs, 2 tables.

AвSTRACT: The southern extreme location and the natural landscapes, highly modelled by glaciers during the Quaternary period, give Tierra del Fuego a unique opportunity to attract visitors worldwide. Its glacial landforms are geodiversity resources that are witness to global climate changes as natural processes. Therefore, this study aims to highlight different glacial landforms considering their geodidactic potential for educational information in terms of geographical study. Sixteen georesources connected by routes are analysed, using bibliographic research, fieldwork and a datasheet designed ad-hoc. Four of them were formed during middle Pleistocene glaciations and the other twelve during the Last Glacial Maximum (LGM), out of which two also represent the Holocene, which happens to be the youngest glaciation.

KEYWORDS: glaciations, landscape, georesources, geodidactic potential, tourist attractions

Corresponding author: Andrea Coronato; andrea.coronato@gmail.com

\section{Introduction}

Almost half a million visitors travel long distances each year to visit Tierra del Fuego. The main reasons are its southern extreme location and its natural landscapes, which are highly modelled by glaciers during the Quaternary period (Coronato et al. 2004a). People from all over the world congregate to have a glimpse of Fuegian nature. Among its biotic and abiotic resources, different glacial landforms outstand and offer an opportunity to learn about global climatic changes along with the natural history of the area, since they are inactive geomorphosites that testify past processes (Reynard 2004, Diolaiuti, Smiraglia 2010). Although these features have a geodidactic potential, currently they only serve as the scenery of tourist experiences (Schwarz 2019). In this sense, geotourism comes out as an alternative way of tourism that focuses on the understanding of geological and geomorphological aspects of a territory by providing services and facilities for interpretation under the scope of Earth Sciences (Hose 1995). These aspects are geodiversity resources (or georesources): abiotic materials and processes from geological, geomorphological or pedological origin (Dixon 1996). Landform geodiversity describes landscape 
complexity from the geomorphological point of view and evaluates all morphogenetic patterns of different types of relief (Zwoliński 2009: 78). Thus, glacial landforms are georesources that can be used, among others, for scientific research and tourism. Dowling and Newsome (2018: 316) state that in many parts of the world glaciated landscapes have long attracted tourists seeking adventure, nature based and/or educational activities. For instance, Jamorska et al. (2020: 12) researched the young glacial lowland in Northern Poland which presented a high level of geotourism attractiveness since it could enable better understanding of processes and formations that occurred during continental glaciations. In Morocco, glacial landforms have been identified as geomorphosites according to a morphogenetic classification. Among the 24 georesources, cirques and U-shaped valleys were selected in Central High-Atlas (Bouzekraoui et al. 2017). Finally, unlike tropical latitudes (Quesada-Román, Pérez-Umaña 2020), the glacial landscape of the Fuegian Andes in subantarctic environments is located in low altitudes, $1500 \mathrm{~m}$ above the sea level; this favours accessibility and use (Migon 2018). However, according to Dowling and Newsome (2018) Andean glacial landscapes such as Upsala, Viedma or Perito Moreno glaciers - though unique - are used as the backdrop where specific adventure activities take place and so could not be considered as geotourism destinations because their educational value is underutilised.

Georesources used as natural tourist attractions promote a link between science and leisure (Schwarz, Migoń 2017) that should not be underestimated. Hence, the aims of this contribution are: (a) to describe glacial landforms as geodiversity resources considering their abundance across Tierra del Fuego and along its glacial history since the mid Pleistocene; (b) to present the didactic potential of these landforms for geotourism purposes.

\section{Tierra del Fuego in southernmost Patagonia (Argentina)}

Tierra del Fuego is the biggest island of the Fuegian archipelago, at the southernmost tip of South America. It is surrounded by the Magellan Strait to the N and NW, the Atlantic and Pacific oceans to the $\mathrm{E}$ and $\mathrm{W}$ respectively, and by the
Beagle channel to the S. Longitude $68^{\circ} 36^{\prime} \mathrm{W}$ separates the island in two administrations belonging to Chile (the western) and Argentina (the eastern one). On the Argentinean side, three main urban localities are connected through the National Route Number 3 with N-S direction and almost 500 km (Fig. 1).

Several physiographic units develop around its $21,600 \mathrm{~km}^{2}$ of extension; from $\mathrm{S}$ to $\mathrm{N}$ they are (Coronato et al. 2008a):

- mountains with evergreen forest and tundra,

- rounded wooded hills with grassy plains,

- semiarid low ranges and grassy steppe plains, and

- low reliefs covered by blanket peatlands and e-coasts.

The orographic frame is made of two morphostructural units where tectonic, glacial, fluvial and littoral landscapes develop: the Fuegian Andes and the Thrust-Fold Belt. The former extends in the $\mathrm{W}-\mathrm{E}$ direction with a maximum elevation of $1480 \mathrm{~m}$ a.s.l.; the latter extends in NW-SE direction with 850-885 m a.s.l., forming the hill and tableland systems in the central and northern part of the region. The territory is under the domain of Cold Humid oceanic climate in the south and centre, changing to Cold Subhumid oceanic northwards. The aridity index is 0.75 and 0.5 , respectively, while the mean annual temperature is $5^{\circ} \mathrm{C}$ in both (Coronato et al. 2008a). The Southern Deciduous Beech forest with Nothofhagus sp. as dominant arboreal species cover the mountains up to $600 \mathrm{~m}$ a.s.l., over it, the Altoandino Desert or Tundra develops with mosses, lichens, grasses and cushioned plants spaced in between rocks and bare soils. In the subhumid region, the Fuegian Steppe, composed of grassy and shrubby species, covers the relief completely. These biomes form the Sub-antarctic phytogeographic province of Argentina (Roig 1998) and extend up to the coasts in their respective areas. The Argentinean region of Tierra del Fuego is inhabited by 173,432 people (IPIEC 2021), distributed in three medium to small cities (Fig. 1a). This means that part of the territory is devoted to nature conservation, mainly at the $S$ and E, and to forestry, farming and oil exploitation at the centre and N. At present, tourism is concentrated in the $S$, where the mountain and forest landscape, as well as the Beagle channel, offer a natural and monumental scenery. 
Small cirque glaciers are present at the Fuegian Andes $>1000 \mathrm{~m}$ a.s.l. They are the relict of a vast glacial landscape that covered the lowlands repeatedly along the Quaternary times (Coronato et al. 2004a). The ancient glaciers spread out from the Darwin Cordillera (Fig. 1a) in all directions. Most of them flowed along the tectonic alignments of the Fuegian Andes into the inland or the present marine environments. According to Coronato et al. (2004a), Rabassa et al. (2000) and Rabassa (2008), five main glacial lobes (Fig. 2) flowed from the Darwin mountain ice-sheet and received several alpine-type glaciers generating a dense glacial network. These glaciers covered the mountains and the lowlands in different cold climatic episodes since the mid-Pleistocene (1 Ma years ago) up to the Last Glacial Maximum (LGM, ca. 25 ka ago).

Figure 2 shows the glacial limits or maximum extension recognised for each glaciation in different colours. The oldest glacial features are represented by relicts of basal till shown in exposures, lateral moraines and by erratic boulders, scattered over the landscape or grouped as boulder

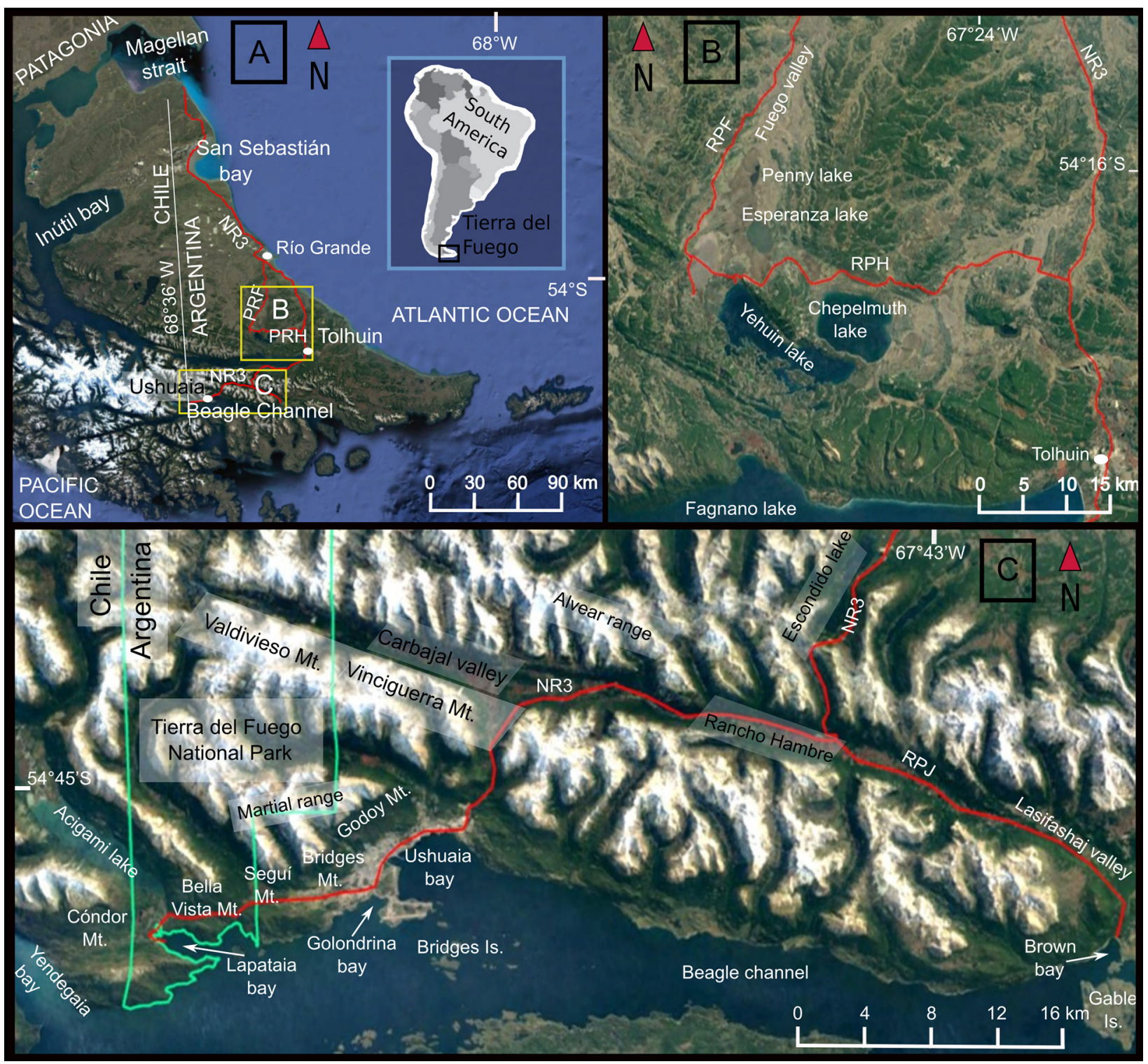

Fig. 1. Isla Grande de Tierra del Fuego map. A - points indicate the cities' location; B - view of a sector of central Tierra del Fuego, where several described landforms are present; C - view of a sector of southern Tierra del Fuego, where most of the landforms are present. The three maps are based on Google Earth ${ }^{\mathrm{TM}}$ images. National Route Number 3 (NR3), the main paved road, communicates the territory mainly in the N-S direction. The others are dirty and provincial routes " $\mathrm{H}$ ", (RPH), " $\mathrm{F}$ " (RPF) and "J" (RPJ). 


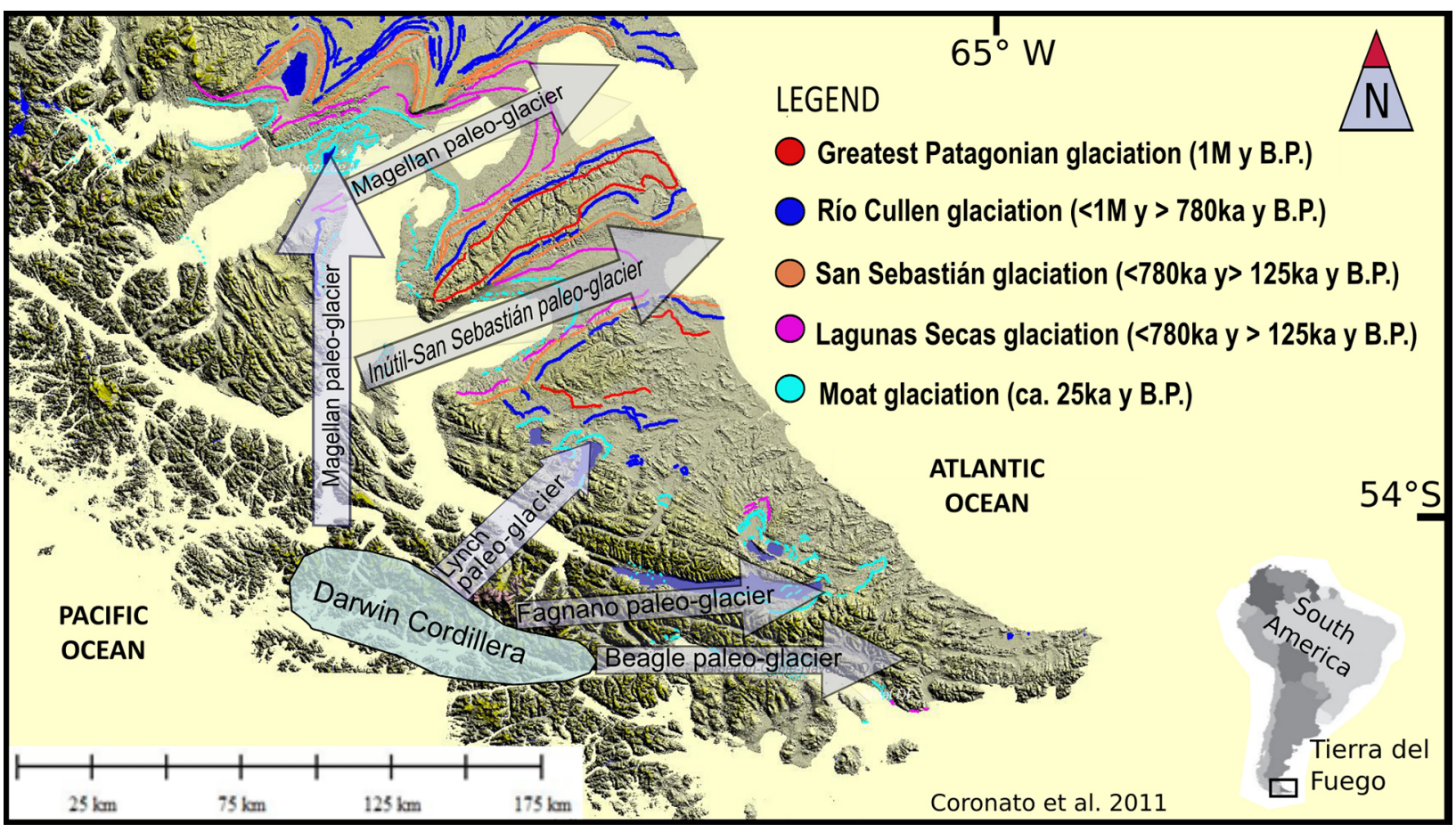

Fig. 2. The main glacial axis dispersed from the Darwin Cordillera ice-mountain sheet flowing in Tierra del Fuego and glacial limits along the main glacial valleys (modified from Coronato and Rabassa 2011). The map is based on Shuttle Radar Terrain Model (90 m resolution).

fields. The main example of the youngest middle Pleistocene glaciation is found along the Fagnano lake cliffs. On its SE coast, there is a huge glaciodeltaic sedimentary sequence (Bujalesky et al. 1997) overlaid by younger basal moraines. All types of glacial landforms and features belonging to the LGM can be recognised along the main and lateral troughs sculptured in the Fuegian Andes.

\section{Geodiversity resources as geotourist attractions}

During the last three decades, the term geodiversity has drawn the attention of researchers worldwide. Nevertheless, the concept still lacks a formal and univocal definition (Ollier 2012, Zwoliński, Stachowiak 2012). Zwoliński (2009) expresses that it is usually used in two meanings: to refer to the whole range of geological, geomorphological and soil phenomena and to refer to particular complex geosystems.

In this paper, geodiversity is used within the first meaning and some authors do as well by referring to it as the variety of abiotic nature as an analogy of the term biodiversity which represents the biological aspects of the environment (Gray 2004). Durán (1999) and Serrano Cañadas and Ruiz Flaño (2007) state that geodiversity is a synonym of geological variety, including lithology, chronostratigraphy, mineralogy, palaeontology, geomorphology and palaeogeography. Additionally, geodiversity is the substratum that supports all ways of life (Nieto 2001). Dixon (1996) classifies geodiversity in three groups of features: geological (rocks), geomorphological (landscapes) and pedological (soils), including the relationships, systems and processes all these involve.

In any case, geodiversity reveals an intrinsic property of all geographical spaces and, at the same time, describes the geological and geomorphological interest of a region; moreover, it hosts information about the past and even the future so that people can understand the natural evolution of a place as well as make predictions (Bruschi 2007).

As biodiversity, geodiversity offers systemic services which make it deserve recognition and protection. Gray (2005) identifies intrinsic, cultural, aesthetic, economical, functional and scientific values and proposes geotourism as a way to use and preserve georesources.

This form of alternative tourism was first defined by Hose (1995: 17) as the provision of 
interpretive and service facilities to enable tourists to acquire knowledge and understanding of the geology and geomorphology of a site (including its contribution to the development of the Earth sciences) beyond the level of mere aesthetic appreciation. This suggests that abiotic natural features are not just the setting and background of tourist destinations but resources that can be used to let locals and foreigners learn about the place they are visiting, how it was formed, when and why.

A distinctive aspect of geotourism is its didactic function (Millán Escriche 2011): visitors get to know the physical components of landscapes, understanding and learning as they travel. As a result, geotourism is a way of modern tourism based on knowledge (Sadry 2009).

The relationship between geodiversity and geotourism makes sense in Tierra del Fuego if its natural history is considered. Many studies carried out in the area prove the interest these terms have aroused during the last decade. Schwarz (2013, 2017, 2019) has studied different Fuegian landscapes considering their geodiversity with the aim of outlining a sustainable development tourism strategy. Schwarz and Coronato (2019) have designed a methodology to identify, assess and classify georesources in order to promote geotourism. Flores (2020) proposed different geotourist products to enhance the urban tourist offer in southern Tierra del Fuego. Cohen et al. (2020) have identified and mapped georesources of different morphogenetic origins in a glacial valley in Cañadón de la Oveja. In this sense, Tierra del Fuego should be considered as a faraway destination capable of fulfilling tourists' expectations as regards interesting and attractive georesources. Among them, glacial landforms offer a unique opportunity to understand glacial processes and natural climate change along with the landscape's evolution.

\section{Materials and methods}

The analysis of landforms as georesources was carried out through the authors' previous work, bibliographic research and fieldwork. A specific datasheet was designed to describe each glacial landform identified and selected considering the authors' experience in both glacial geomorphological research and tourism activity. This data collection tool includes: mapping and location considering the geographical coordinates, taken from Google Earth ${ }^{\mathrm{TM}}$, at which the georesource can be appreciated; and the description of the different landforms regarding their

Table 1. Datasheet designed to collect information about each glacial landform.

\begin{tabular}{|c|c|c|c|c|}
\hline \multicolumn{5}{|c|}{ LANDFORM: } \\
\hline \multicolumn{5}{|l|}{ Picture } \\
\hline \multicolumn{5}{|c|}{ LOCATION } \\
\hline Coordinates & & & Access: & \\
\hline \multirow{5}{*}{$\begin{array}{l}\text { TYPE OF } \\
\text { GLACIAL } \\
\text { LANDFORM }\end{array}$} & \multirow{5}{*}{ Erosional } & \multirow{3}{*}{ Abrasion } & \multirow{5}{*}{ Depositional } & $\begin{array}{l}\text { Stratified } \\
\text { drift }\end{array}$ \\
\hline & & & & Till \\
\hline & & & & Frontal \\
\hline & & \multirow{2}{*}{ Plucking } & & Marginal \\
\hline & & & & Subglacial \\
\hline \multicolumn{5}{|l|}{ CHRONOLOGY } \\
\hline \multicolumn{5}{|l|}{$\begin{array}{l}\text { GEO- } \\
\text { DESCRIPTION }\end{array}$} \\
\hline \multicolumn{5}{|l|}{$\begin{array}{l}\text { GEODIDACTIC } \\
\text { FUNCTIONS }\end{array}$} \\
\hline OTHERS & & & & \\
\hline
\end{tabular}


genetic processes. A classification into erosional (abrasion or plucking) or depositional features (type of drift and relative position to the ice) and into the chronological frame is included (Table 1 ). The glacial landforms offer different geodidactic functions, such as the possibility to learn about different morphogenetic processes (transport, erosion or deposition) and about climatic and environmental changes that occurred in the middle Pleistocene as ancient glaciations, late Pleistocene as LGM and Holocene-centennial glaciations as the youngest ones.

After collecting and organising all the data, the glacial georesources described herein were located and mapped according to the type of landform. Considering the adequate extent of this paper, the datasheet of each landform is not included, instead, a brief summary of each one is presented.

\section{Results}

Of all the glacial landforms (L) present in the Fuegian landscape, only 16 have been selected for this analysis (Fig. 3). Four landforms correspond to the middle Pleistocene period whereas twelve to the LGM, two of which also include the youngest glaciations. $37.5 \%$ of the georesources represent erosional features, $37.5 \%$ are depositional and the other 25\% depict both.

Among the middle Pleistocene landforms, the following four have been selected:

\section{L1. Pampa de Beta moraine $\left(52^{\circ} 48^{\prime} \mathrm{S}, 68^{\circ} 35^{\prime} \mathrm{W}\right.$, Fig. 4)}

Depositional landform composed of basal till formed by an ancient ice-cap that covered the territory as a continental glacier not well recognised as channelised glaciers. Till deposits are intercalated with clast supported gravel strata (Díaz Ballochi et al. 2018). As the surface is quite plain (95-85 $\mathrm{m}$ a.s.l.), with a gentle slope eastwards $(<1 \%)$, it could be also interpreted as a till plain (Díaz Ballochi et al. 2020). It is deeply dissected by retrograding, temporary channels. In some exposures, ice-wedge features are shown, indicating that the area was part of a cold desert or tundra sometime during any or several later glaciations that occurred along the Pleistocene. The estimated age is the middle Pleistocene, calculated by comparison with the regional glacial model of Southern Patagonia, where this glacial advance was dated ca. 1 Ma years ago (Meglioli

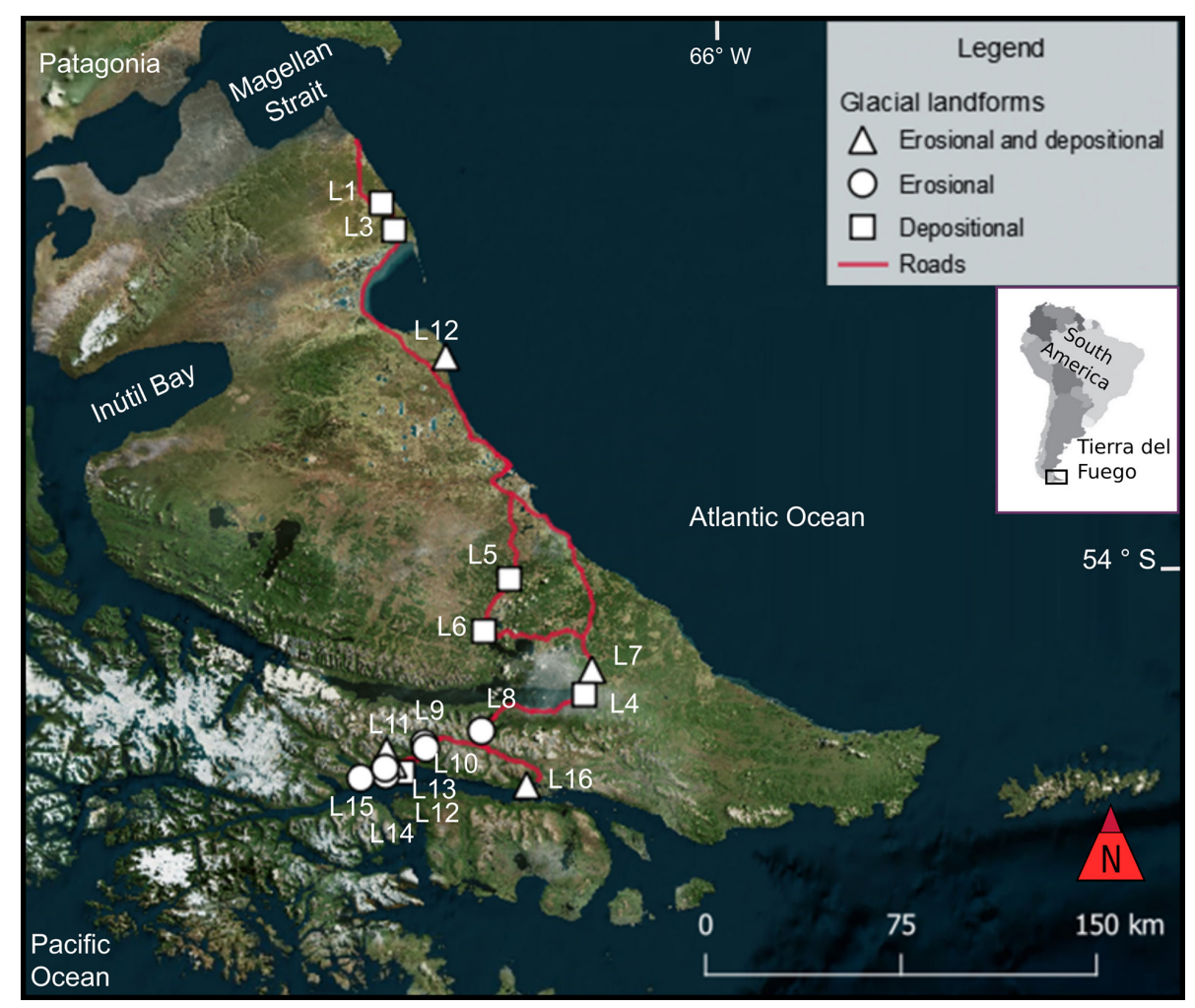

Fig. 3. Location of the 16 glacial landforms herein presented. 


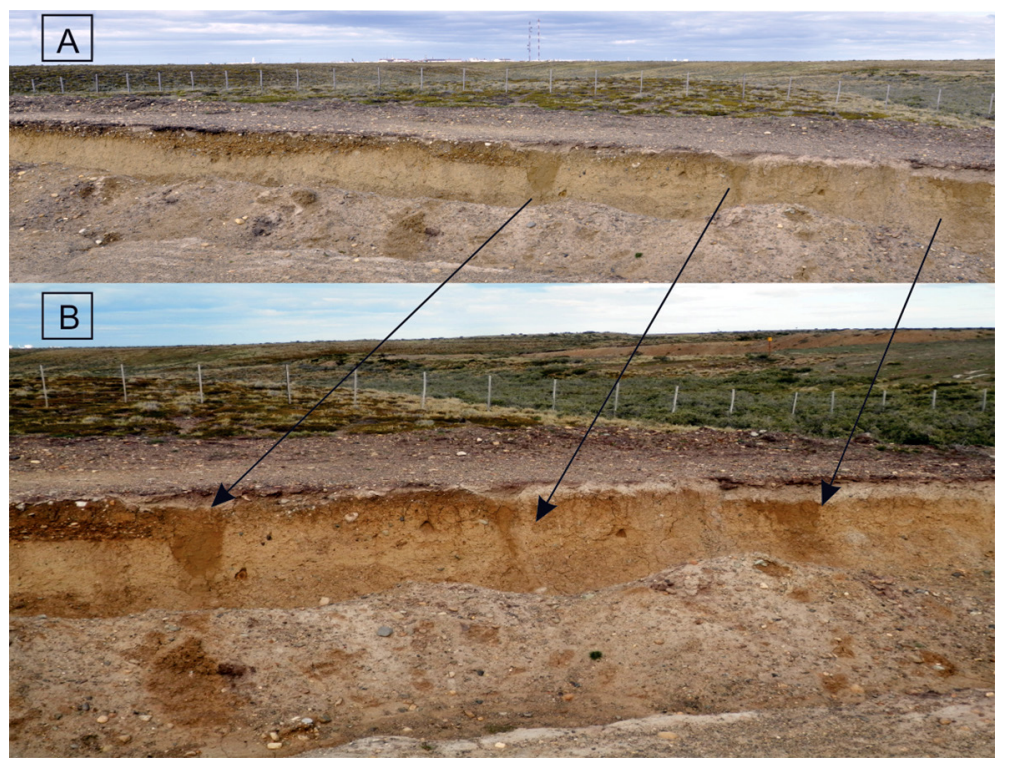

Fig. 4. View of Pampa de Beta moraine smooth relief and ice-wedges casts indicating that the region was a tundra desert during the following Pleistocene glaciations.

1992, Coronato et al. 2004a, b, Coronato and Rabassa 2011). This glaciation is known as the Great Patagonian Glaciation or GGP (Fig. 2) and is considered as the biggest ice-cover that had existed in the southernmost part of South America and in Tierra del Fuego (Coronato et al. 2004b). Regionally, it was mapped as the Pampa de Beta glaciation (Meglioli 1992). It is placed in Cullen Ranchlands which are devoted to cattle raising as well as to oil and gas exploitation carried out by private companies. The NR3 crosses it in an N-S direction, which favours its visit.

\section{L2. Punta Sinaí moraine and boulder field $\left(56^{\circ} 24^{\prime}\right.$ S, $68^{\circ} 04^{\prime}$ W, Fig. 5a, b and c)}

Depositional landform composed of endo and supraglacial till formed by the Inútil-San Sebastián paleo-glacier (Fig. 2). It is a lateral moraine with knob and kettle surface morphology and more than one hundred granodiorite erratic boulders of 6-250 $\mathrm{m}^{3}$ in volume, scattered on the southern morainic edge. They form one of the erratic boulder trains developed along the southern margin of the Inútil-San Sebastián paleoglacier (Darvill et al. 2015). Most of the boulders lay in the kettles but others are inside the till, which is being exposed to wave erosion. In several sectors, the till includes stratified sandy and gravelly beds with glaciotectonic structures. The original moraine extension was $40 \mathrm{~km}$ eastwards, into the sea where the frontal moraine location is assumed
(Isla, Schnack 1995); several boulders appear during the low tides along with this extent. The boulders show weathering, cracks and fractures resulting from cryoclastism. The estimated age of the moraine is middle Pleistocene based on Brunhes magnetic polarity times (Walther et al. 2007), deposited during the glaciation known as the Post GGP 1 (Coronato et al. 2004a, Coronato and Rabassa 2011) or Río Cullen, sensu Meglioli (1992). The present and historical weathering condition of boulders did not allow the proposal of an absolute chronology by cosmogenic isotopes (Kaplan et al. 2007). The georesource is located in Sara Ranch, a private land devoted to cattle raising and oil extraction. A permission to access is needed. This georesource has already been proposed as a site of geological heritage by Schwarz et al. (2014) and is beginning to be used for recreational visits organised by the local tourism board.

\section{L3. San Sebastián moraine $\left(52^{\circ} 58^{\prime} \mathrm{S}, 6^{\circ} 23^{\prime} \mathrm{W}\right.$, Fig. 5d, e)}

Depositional landform composed of till formed by the ancient Inútil-San Sebastián paleo-glacier (Fig. 2), in its northern edge. It is a lateral moraine with knob and kettle surface morphology, also known as a hummocky moraine type, characterised by the presence of mounds and holes. An average size of $50 \mathrm{~m}$ in diameter and $4 \mathrm{~m}$ in depth has been calculated by Díaz Ballochi et al. (2020). This morphology resulted from the ice collapse 


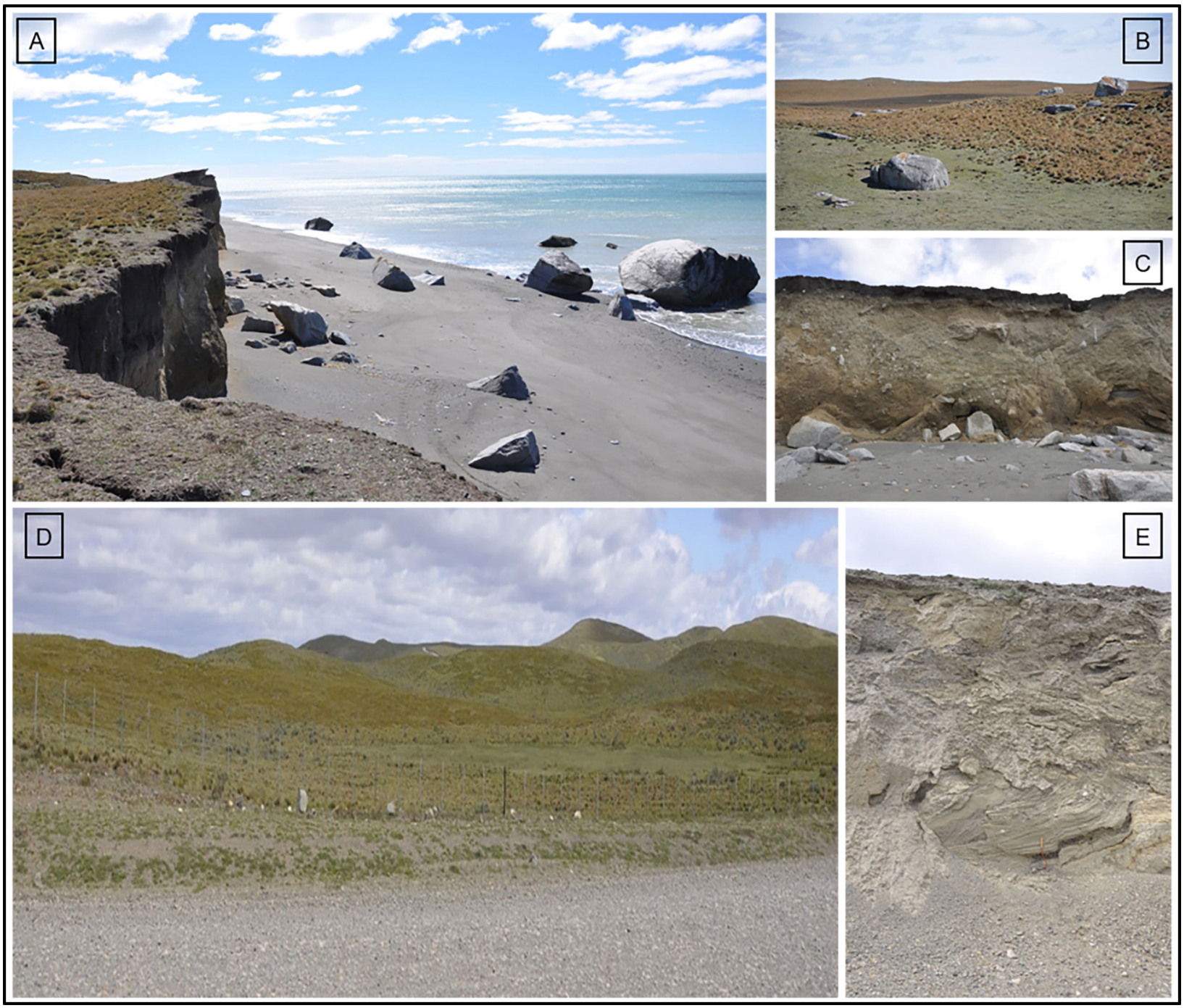

Fig. 5. Punta Sinaí moraine and erratic boulders field. A - the moraine developing a cliff due to wave erosion and boulders scattered in the beach; B - hummocky moraine surface with boulders; C - till exposure eroded by wave-action showing endoglacial boulders; D - San Sebastián moraine: view of the hummocky relief of the lateral moraine complex; E - till exposure showing stratified and deformed strata.

over the glacier surface after ice disintegration due to fast thickness. The moraine extends in the S-E direction up to the coast, where the receding cliffs show the till composition, which sometimes includes fossil gastropods taken from the marine sedimentary rocks overridden by the glacier. Interesting sedimentary structures of bedding and till deformation could also be observed in an open quarry accessible by a trail at the western side of the main route. The estimated age of the moraine is middle Pleistocene or Post GGP 2 sensu Coronato et al. (2004a). Regionally, it was named as the Sierras de San Sebastián Moraines (Meglioli 1992). This georesource is placed in Cullen Ranchlands. The multiple dirty roads to reach the abundant oil extractor pumps have greatly eroded the moraine surface. The NR3 crosses the moraine in the N-S direction, which favours the observation of its interesting surface morphology.

\section{L4. Paleo-delta kame and basal moraine on Fagnano lake shore $\left(54^{\circ} 33^{\prime} \mathrm{S}, 6^{\circ} 13^{\prime} \mathrm{W}\right.$, Fig. 6$)$}

Depositional landforms composed of the two types of drift deposited by the Fagnano paleo-glacier (Fig. 2). This is a sequence of stratified drift of lacustrine silty-clays over which several gravel strata lay to form an ancient delta-kame. Over it, a basal moraine is placed. The typical deltaic depositional structure shows the bottom set, the foreset and the top set of gravel strata. The prograding or advancing foreset strata into the ancient 
lake is clearly visible in some places. The yellowish-orange colour of the gravels reflects weathering by oxidation. The top set is mainly sandy with scattered lacustrine deposits full of diatoms species of cold, freshwater environments (Bujalesky et al. 1997). The paleo-delta kame deposits are overlaid by till which formed a basal moraine extending along the southern and eastern coast of the lake (Coronato et al. 2009). At present, it is possible to appreciate these two types of glacial deposits due to wave erosion, slumps and rock falls, which have modified the original aspect of the delta kame and the basal moraine and turned them into cliffs. This moraine includes several ancient peat layers radiometrically dated between

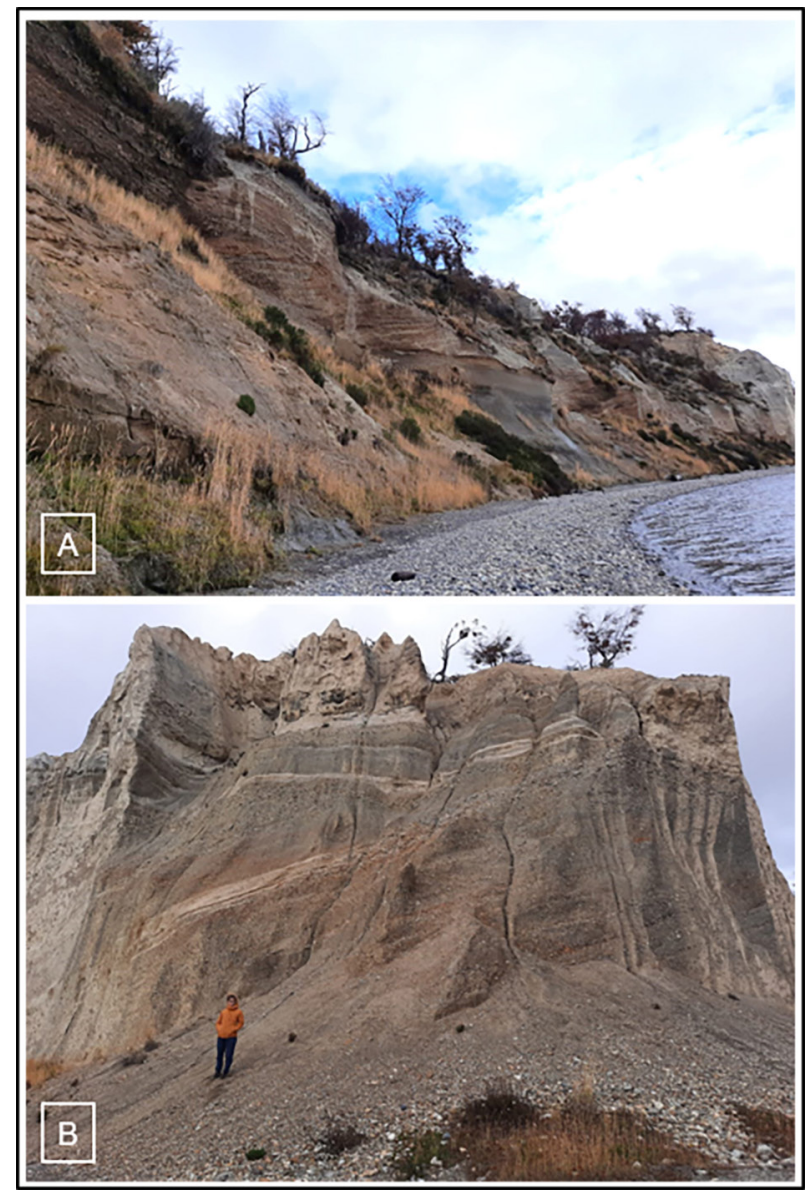

Fig. 6. Paleo-delta kame and basal moraine on Fagnano lake shore. A - general view of the paleodelta kame deposits (to the west); the basal grey lacustrine sediments of the bottom set, the foreset gravel strata and the top set sandy-gravelly strata can be distinguished along with the exposure; B - section showing the three components of the paleo-delta kame sedimentary sequence and columnar basal till on the top. While the delta deposits belong to the last middle Pleistocene glaciations, the basal till is from the LGM.
39 and $58 \mathrm{ka}$, close to the ${ }^{14} \mathrm{C}$ limit (Bujalesky et al. 1997). These layers chronologically position the top of the sequence as previous to the LGM or late Pleistocene in age. The relative age of the delta kame depositional sequence is interpreted as middle Pleistocene based on the fact that it has been understood as a consequence of the retreat of one of the glaciations that occurred during that lapse (Bujalesky et al. 1997). As this georesource is placed on the Fagnano lake coast, visitors can walk by themselves along the shore taking care of their own safety. It is not recommended to climb the cliffs nor hike through deep gullies. The starting point of the visit could be the shore located northeastwards, at the Turbio river mouth, where a dirty road is connected to NR3.

Among the late Pleistocene landforms, the following 16 have been selected:

\section{L5. Río Fuego terminal moraine complex (54 $4^{\circ}$ ' S, 67ํ1' W, Fig. 7a)}

Depositional landform complex placed transversely to the Fuego valley (Fig. 1b). It is $85-150 \mathrm{~m}$ a.s.l. and at least $40 \mathrm{~m}$ above the valley floor. Its lateral continuity can be seen along the eastern side of the valley at the foothills; along the western side, RPF crosses the moraines and visitors drive through these landforms without noticing them. The complex has been interpreted as three morainic arcs developed between the Buenos Aires Ranch settlement and Penny shallow lake. It has been deposited by the Fuego paleo-glacier, an ice lobe of $45 \mathrm{~km}$ long that flowed S-E from the Fagnano paleo-glacier - the main ice lobe of the region, developing an ice-divergence (Fig. 2). While the outermost Buenos Aires moraine indicates the maximum extent of the ice during the LGM, the Miramonte (intermediate) and Penny (innermost) moraines show two ice positions during its general retreat (Coronato et al. 2008b). They have been correlated with Glacial Stage B in the Inútil-San Sebastián bay (Mc Culloch et al. 2005), the estimated age is $25-23 \mathrm{ka}$. The landforms are placed in different cattle raising ranches settled along the Fuego valley but they could be appreciated from the above-mentioned dirty road.

\section{L6. Yehuin moraine and paleo-lake $\left(54^{\circ} 21^{\prime} \mathrm{S}\right.$, $67^{\circ} 48^{\prime} \mathrm{W}$, Fig. $7 \mathrm{~b}$ )}

The two landforms are depositional and were formed in a frontal paleo-ice position. The 
moraine surrounds the present Yehuin lake on its northwestern side while the paleo-lake extends in the N-S direction (Fig. 1b). This is the innermost morainic arc of the Río Fuego sequence, separated $15 \mathrm{~km} S$ from the Penny moraine, described in L5. Its elevation is almost $100 \mathrm{~m}$ a.s.l. and $65 \mathrm{~m}$ above the lake shore. On top of the moraine, several peat bogs are developed in ancient, shallow lakes. The paleo-lake can be observed as a plain that extends from this moraine to the inner one of the Río Fuego complex along $12 \mathrm{~km}$ in which several ponds develop, being Esperanza and Penny shallow lakes the biggest ones. This plain is at 68-59 $\mathrm{m}$ a.s.l. and is partially covered by an alluvial fan which deposited fine sandy-gravel strata on the upper paleo-lake deposits that can be seen on quarries by the route. The Yehuin moraine has been interpreted as the youngest recessional

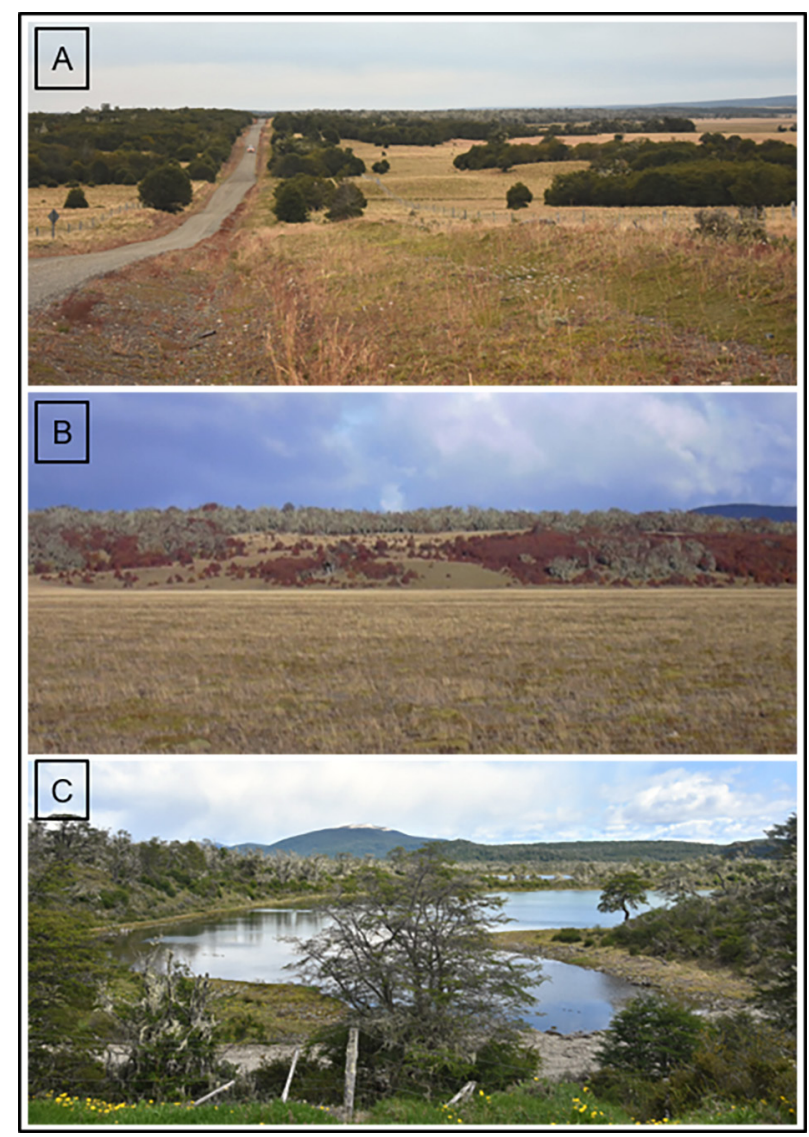

Fig. 7. Landforms belonging to the LGM in central Tierra del Fuego. A - Río Fuego terminal morainic complex facing the $\mathrm{N}$ along with RPF in the western side of the valley; B - Yehuin moraine and paleo-lake view to the SW; in front, the flat relief of the paleolake at the foot of the moraine; $\mathrm{C}$ - Tolhuin kettle and mound topography seen besides NR3; the kettle was

flooded by meltwater forming shallow ponds. stage of the Río Fuego paleo-glacier during the LGM and named as Fu IV after Coronato et al. (2008b). It was correlated to Glacial Stage C, between ca. 21-20 ka B.P. or as Glacial Stage D, $<17$ ka B.P., for the Inútil bay (McCulloch et al. 2005). This controversy is not solved yet due to the lack of organic matter to obtain radiometric absolute ages. The paleo-lake has neither an absolute age but it is assumed to be an ancient proglacial lake that gathered the meltwaters when the Yehuin moraine was forming and was dammed by the inner moraine of the Río Fuego complex (Coronato et al. 2008b). Although absolute ages are not available, it is estimated as the same as that of the Yehuin moraine. The moraine and the western part of the paleo-lake are crossed E-W by $\mathrm{RPH}$ are placed in Esperanza and Rivadavia ranches. The given coordinates correspond to the maximum elevation of the route above the moraine, from where these landforms can be seen. A private neighbourhood called La Rinconada is developed on the SE slope of the moraine. The paleo-lake is observable from RPF to the E and is placed in Los Cerros and Esperanza ranches which are devoted to cattle raising and forestry.

\section{L7. Tolhuin kettles and mounds $\left(54^{\circ} 27^{\prime} \mathrm{S}\right.$, $64^{\circ} 11^{\prime} \mathrm{W}$, Fig. 7c)}

Erosional and depositional landforms composed of depressions and mounds. This hummocky landscape is typical of ice-disintegration processes when the frontal part of thin glaciers are disconnected from the ice body. While the depressions are shallow lakes or peat bogs, the mounds are low hills composed of gravel. A group of several tens of these landforms is placed between the front of a recessional moraine at the SW, where the town of Tolhuin is located, and a glaciofluvial plain at the NE (Fig. $1 b)$. They occupy the ancient ablation plain of the Fagnano paleo-glacier on the valley bottom and are surrounded by rocky hills and other glacial landforms (Coronato et al. 2009). Large deadice blocks scattered and melted in the landscape surrounded by meltwater streams that flowed from the front of the glacier. Those streams deposited gravel and sand around the ice blocks which progressively melted forming the feature of the depressions. The depth of the lakes is not known, but a minimum of $2 \mathrm{~m}$ could be estimated considering the average thickness of the 
peat bogs that developed in them. The mounds are between $9 \mathrm{~m}$ and $2 \mathrm{~m}$ above the lake shores. These landforms represent the Recessional Phase 1 of the LGM (earliest late Glacial) along with the Fagnano lake glacial axe (Coronato et al. 2009) and are comparable to Stage C (McCulloch et al. 2005) when glaciers receded before 21-20 ka B.P. The landforms can be observed from NR3 along $6 \mathrm{~km}$ northwards to Tolhuin in private small rural settlements.

\section{L8. Paso Garibaldi col and lateral valleys $\left(54^{\circ} 41^{\prime} \mathrm{S}, 67^{\circ} 50^{\prime} \mathrm{W}\right.$, Fig. 8a and b)}

Erosional landform resulting from ice-disfluency among different valley glaciers. It is a low section of the arete along the summit line $(850 \mathrm{~m}$ a.s.l.) which connects lateral glacial valleys in opposite directions. It is sculptured at $440 \mathrm{~m}$ a.s.l. in the lowest point of the Alvear range (Fig. 1c). To the N, the Escondido lake occupies the bottom of a deep trough eroded by a lateral glacier of the Fagnano paleo-glacier, where the homonymous lake is located. Its frontal moraines, placed at
$140 \mathrm{~m}$ a.s.l., separate the valley from the basal and lateral moraines of the Fagnano ice lobe and could be visible from the balcony of the col. The ancient glacier that modelled this deep valley would have had at least $250 \mathrm{~m}$ of thickness and received other minor alpine and cirque glaciers from the surroundings. To the $\mathrm{S}$, the Rancho Hambre hanging valley develops between $480 \mathrm{~m}$ a.s.l and $280 \mathrm{~m}$ a.s.l, with a relative altitude of $135 \mathrm{~m}$ a.s.l. in regards to the main valley, the Lasifashaj one, where a huge alpine paleo-glacier flowed NW-SE reaching the Brown bay at the present Beagle marine channel (Fig. 1c). The step or threshold between both valleys is pointed out by the increasing river gradient, although it is only visible by maps or satellite images due to the dense forest cover. The minimum ice thickness is estimated at least at $340 \mathrm{~m}$. An asymmetry in-depth and the relative altitude related to their main valleys are observable between both lateral troughs, probably due to the geological structure of the Fuegian Andes. Striations, or abrasion features, are visible in Roche-moutonneé rocks sculptured on
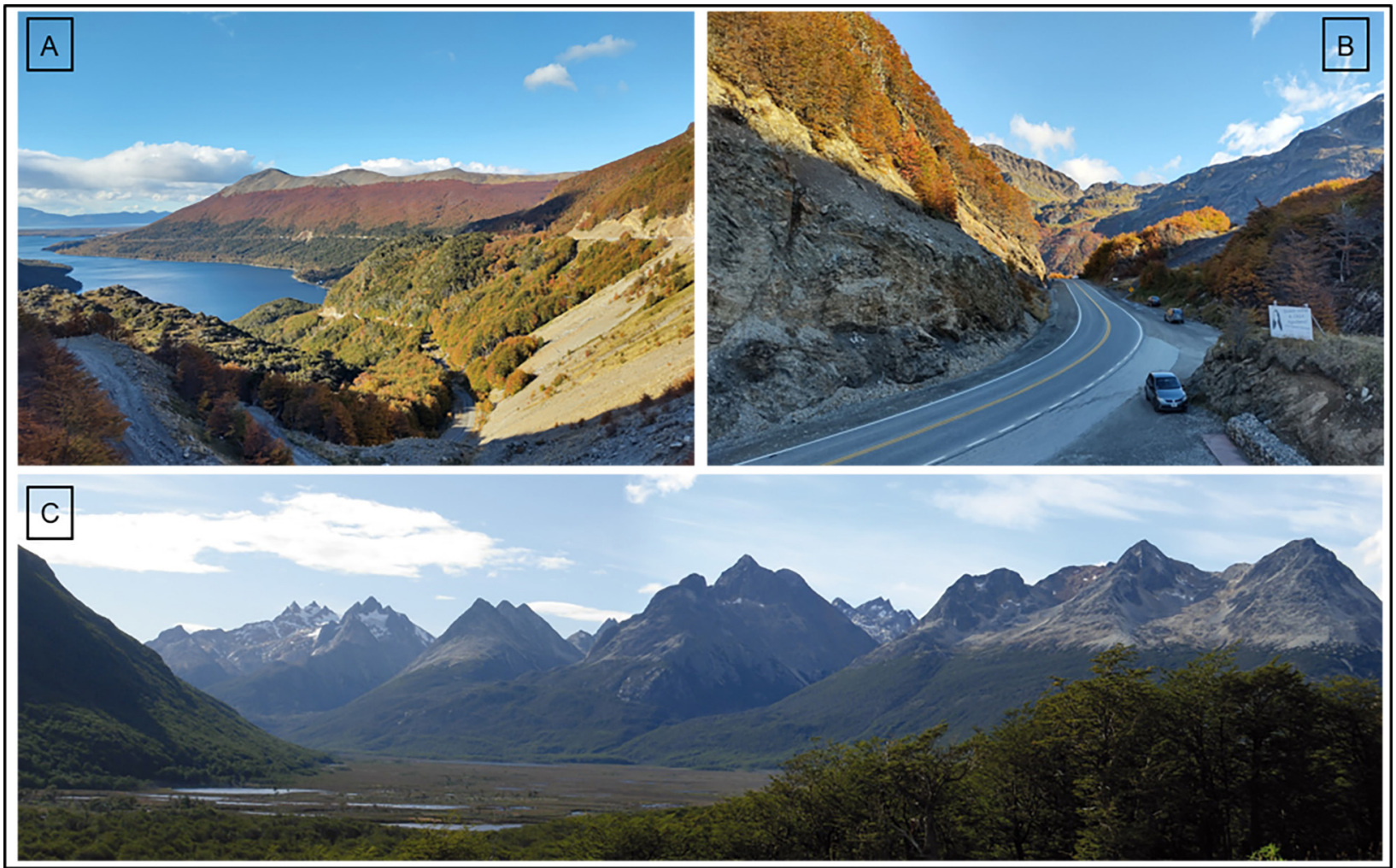

Fig. 8. Erosional features in the Fuegian Andes. View from the col of the lateral glacial valleys developed to the N; A - Escondido lake valley and to the S, B - Rancho Hambre valley. C - Carbajal trough showing aretes, horns, cirques, cirque glaciers and neves, hanging valleys, truncated spurs sculptured on Alvear range, on the northern side of the valley; the wide bottom of the trough is covered by Sphagnum magellanicum peat bogs and ponds. The tree-line is at $650 \mathrm{~m}$ a.s.l. 
volcanic rocks of the col. The col and the valleys resulted from the LGM event but they must have been eroded and deepened during all the glaciations that affected the Fuegian Andes. NR3 crosses the landforms N-S. Lands are property of the provincial administration, devoted to recreational activities. A viewpoint built on the col allows people to appreciate the landscape.

\section{L9. Carbajal-Lasifashaj trough $\left(54^{\circ} 44^{\prime} \mathrm{S}, 68^{\circ} 10^{\prime}\right.$ W, Fig. 8c)}

Erosional landform induced after an integrated glacial system was formed by the paleo-glacier Carbajal-Lasifashaj, the main outlet glacier, and many alpine glaciers that joined it from the Vinciguerra, Valdivieso and Alvear ranges (Fig. 1c). This trough occupies a $100 \mathrm{~km}$ long major thrust fault, with an NW-SE direction. In some part, during the LGM, a transfluent ice lobe flowed to the $S$ through the Olivia valley to the Beagle Channel (Fig. 1c). Several erosional landforms such as aretes, horns, cirques, hanging valleys and truncated spurs can be observed in the northern range of the valley. No depositional landforms associated with the LGM can be identified here since this was the ice accumulation zone, except for some till deposits at the bottom of the valley. Also, several Sphagnum magellanicum peat bogs cover the valley bottom, pointing out the presence of ancient shallow lakes formed after deglaciation. Some slopes show geomorphic evidence of rock and debris slides (Schwarz, Migoń 2017). This landform is a typical trough and is being used for environmental interpretation through a panoramic viewpoint and a panel that is $17 \mathrm{~km}$ far from Ushuaia, along NR3. It can be visited all year round. The area is also used for hiking and part of the trough is included in a multiple-use reserve devoted to tourism and recreation. Mining also exists in a peat bog in the southwestern part of the valley, close to the main road.

\section{L10. Olivia paleo-nunatak $\left(54^{\circ} 44^{\prime} \mathrm{S}, 64^{\circ} 10^{\prime} \mathrm{W}\right.$, Fig. 9a)}

An erosional landform located in the Sierra Sorondo that resulted after being surrounded by the Olivia and Cinco Hermanos paleo-glaciers flowing to the Beagle one (Fig. 2), the main ice lobe of the region (Coronato 1995). Its present peaks, ranging between $1300 \mathrm{~m}$ a.s.l and $1476 \mathrm{~m}$ a.s.l., emerged from the ice which reached at least $800 \mathrm{~m}$ of thickness from the valley floor. The highly quarried rocks on slopes allow us to observe the Andean folding and lifting affecting marine meta-sediment deep watershed rocks that make up the Yaghan Formation, aged old Lower Cretaceous (Coronato et. al. 2017). Small cirque glaciers remain on the SE-facing slope of the mountain. This nunatak was formed during the LGM when an ice network covered all the mountain valleys of the Fuegian Andes. This landform can be seen from everywhere in Ushuaia being an icon of the city for residents and tourists. The whole view of the Olivia Mt. can be appreciated from NR3, $10 \mathrm{~km}$ NE to Ushuaia downtown. Due to high rock weathering and steep slopes, hiking is not recommended while climbing is possible only for experts.

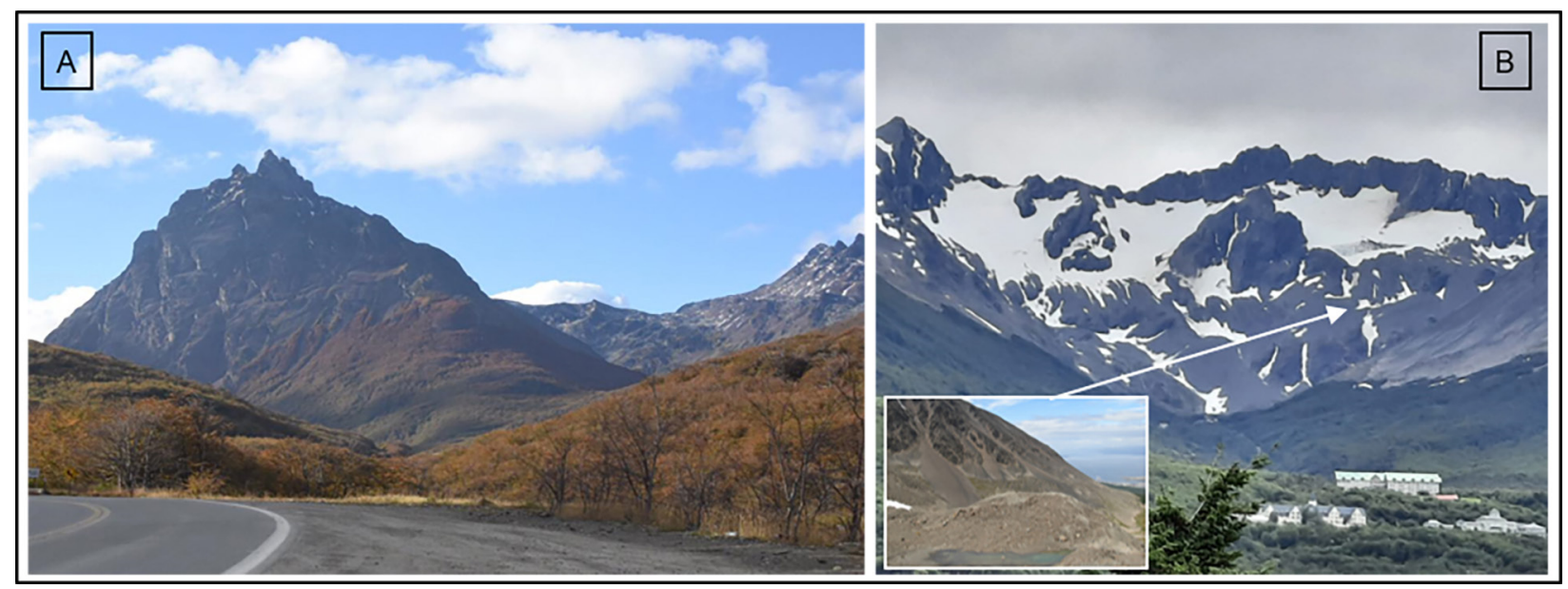

Fig. 9. Glacial features around Ushuaia city. A - Olivia paleo-nunatak and cirques developed in its eastern slope; B - Le Martial cirque glacier and valley; in the small picture a detail of the Late Glacial and LIA moraines are pointed out. 


\section{L11. Le Martial cirque ( $54^{\circ} 47^{\prime} \mathrm{S}, 6^{\circ} 23^{\prime} \mathrm{W}$, Fig. 9b)}

Erosional landform located in the Martial range, between the Bridges (1072 $\mathrm{m}$ a.s.l.) and Godoy (1214 m a.s.1.) Mts. (Fig. 1c). It is multiple cirques composed of three others, separated by rocky outcrops (Planas et al. 2002). The cirque floor is located between 450 m.a.s.l and $800 \mathrm{~m}$ a.s.l. According to Planas et al. (2002), based on glacial morphology, the glacier expanded after the late Glacial, however, no dates are yet available. The formation of moraines of Fase IV must correspond to the middle-late Holocene to the XVI-XVIII period (Little Ice Age or LIA), resulting in a set of frontal moraines located a few meters in front of the glacier. Other geomorphological pieces of evidence are those from the LGM and late Glacial as lateral, central and terminal moraines along the slopes and in the cirque bottom as well as an eroded glaciofluvial plain (Planas et. al. 2002). The cirque was occupied by a cirque glacier of at least $600 \mathrm{~m}$ of thickness which joined the main Beagle paleo-glacier during the LGM as a unique ice-mass (Rabassa et al. 2000). The cirque can be accessed all year round from Ushuaia city. At present, the cirque floor and the Martial glacier are used by residents and tourists for different recreational activities such as trekking, sky, snowboard and canopy in the forested slopes.

\section{L12. Ushuaia peninsula basal moraines ( $54^{\circ} 49^{\prime}$}

\section{S, $68^{\circ} 18^{\prime}$ W, Fig. 10)}

Depositional landforms composed of basal till formed by the Beagle paleo-glacier and jointed by a Holocene raised beach as a tombolo, leaving Golondrina bay to the $\mathrm{W}$ and Ushuaia bay to the E (Fig. 1c). Drumlin-like landforms and depressions covered by peat bogs are observed in some places; also, glacial ice eroded rocky outcrops on shales. The Ushuaia peninsula is made up of two basal moraines with a maximum elevation of $30 \mathrm{~m}$ a.s.l. It has an irregular coastline with beach and cliff development. This landform is located in the southern part of Ushuaia city, so visitors and local people make use of the enabled lands for military, scientific, recreational and transportation purposes. Ushuaia's international airport is located on the southern moraine. The original shape of these landforms was highly modified by anthropic actions after its building (Bujalesky et al. 2008). An exceptional view of the entire peninsula can be achieved on the way to Le Martial cirque,

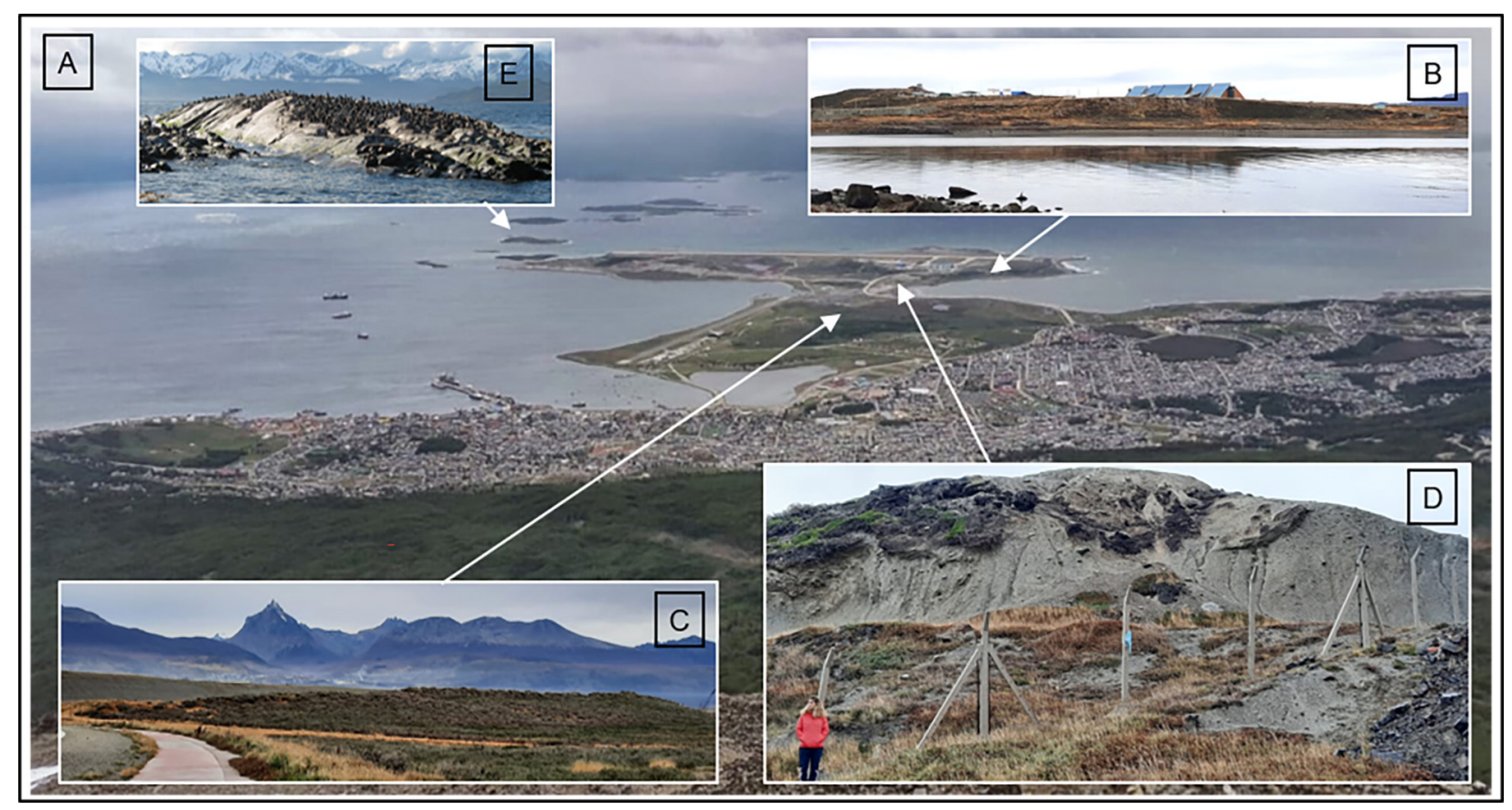

Fig. 10. A - Ushuaia Peninsula basal moraines in Ushuaia city surroundings and rocky stream-lined islands in the Beagle Channel; B - basal moraine flattened by the airport construction, the visible building; C - basal moraine topography forming part of the peninsula; D - basal till exposure showing few boulders into a siltyclay matrix; E - glacial abrasion on the rocks of the island where marine mammals live in colonies. 
described in L11. Southeast of the peninsula, the Bridges Is., a set of rocky islands, emerge from the Beagle channel waters. They are glacial stream-lined landforms according to the W-E paleo-glacier flow direction. They are formed by the same metasedimentary rocks of the Ushuaia peninsula and some of them show striations and hold erratic boulders. They represent the emerging part of one of the thresholds of the Beagle trough; they have a maximum elevation of $25 \mathrm{~m}$ a.s.l. rising from $20 \mathrm{~m}$ b.s.l. and very close to the 120-140 m b.s.l. at the bottom of the channel on this part (Bujalesky et al. 2008). These islands can be visited by boat, some excursions even include short walks on them.

\section{L13. Susana Mount (54 $50^{\prime} \mathrm{S}, \mathbf{6 8}^{\circ} \mathbf{2 5}^{\prime} \mathrm{W}$, Fig. 11a)}

Erosional landform with $505 \mathrm{~m}$ a.s.l. with $\mathrm{W}-\mathrm{E}$ direction in its longer axis. This mount stands out due to its rounded summit, very different from the steep slopes of the surrounding mountains. It is composed of meta-marine sedimentary rocks with quartz vein intrusions. At its feet, in its northern slope, a basal till is placked against the rock. Also, active mass wasting processes such as rock-falls and debri-falls have developed. Its particular longitudinal and rounded shape is the result of being covered by two paleo-glaciers during the LGM, the Pipo and Beagle ones (Coronato 1995). The former flowed along a valley eroded between Susana, Bridges and Godoy Mts. Climatic improvement after the LGM caused these glaciers to begin to decrease in thickness, causing separation and disconnection between both glaciers and allowing Susana Mt. to emerge. The Pipo paleo-glacier became a dead ice mass hosted in the trough (Coronato 1993). At present, the western sector of Susana Mt. is under nature conservation by the Tierra del Fuego National Park, but the N, E and S slopes are not; instead, they were once used for livestock and today for urban development, which contributes to slope erosion processes. The foot and medium southern slopes of this landform can be accessed by walking, car or horse, up to the Costa Susana urbanisation. From there, a $1.5 \mathrm{~km}$ long trail climbs up to the summit along a slope of $25 \%$ average inclination. Trekking and horseback riding are promoted by travel agencies to get a $360^{\circ}$ view from the summit to both the mountains and the Beagle channel.

\section{L14. Cañadón de la Oveja trough $\left(54^{\circ} 49^{\prime} \mathrm{S}\right.$, $68^{\circ} 24^{\prime}$ W, Fig. 11b)}

Erosional landform excavated by the homonymous paleo-glacier between the Bridges (1072 m a.s.1.) and Seguí (1192 m a.s.l.) Mts. It extends along $5 \mathrm{~km}$ to the $\mathrm{SE}$, developing three steps in its longitudinal profile, between 600 and 490 m.a.s.l. At the end of the valley, a rocky threshold of $595 \mathrm{~m}$ a.s.l separates this trough from the Río Pipo one, to which it is joined. The maximum elevation of the summits reaches $1261 \mathrm{~m}$ a.s.l. Cirques and cols could be distinguished in the valley header as well as receding cirque glaciers, snow-patches and moraines. On the lateral slopes, debris sheets and debris avalanche occurred. It is a typical U-shaped valley with steep rocky and debris slopes on both sides and an almost plain valley floor. Based on the altitude of the nickpoint at 850-900 $\mathrm{m}$ a.s.l, an ice depth of the paleo-glacier of at least $500 \mathrm{~m}$ can be interpreted. The entire trough was sculptured during the LGM (Coronato 1995), although the header was also covered by ice during the youngest glaciations during the middle to late Holocene or during the LIA. The absence of vegetation cover, the fresh morphology and the ice nearness of the moraines can be interpreted as they were formed during the LIA, as it was pointed out for Le Martial youngest moraines described in L11. However, this is not yet concluded due to the lack of material to be dated. An exceptional view of the entire landform can be obtained from NR3 on the way to the Tierra del Fuego National Park or from Susana Mt. summit, described in L13.

\section{L15. Lapataia trough $\left(54^{\circ} 51^{\prime} \mathrm{S}, 68^{\circ} 34^{\prime} \mathrm{W}\right.$, Fig. 11c)}

Erosional landform known as Lapataia bay, modelled in between Cóndor range (maximum elevation $1238 \mathrm{~m}$ a.s.1.) and Mesa Real Mt. (700 m a.s.1.) and partially flooded by marine waters (Fig. 1c). It is a U-shaped valley formed by glacier disfluency towards E from a paleo-glacier which joined the Beagle one in the N-S direction. Before this junction, the glacier turned to the $\mathrm{E}$, flowing between the above-mentioned mountains and joining lateral cirque and alpine glaciers placed at the Cóndor range, $>550 \mathrm{~m}$ a.s.l. On the contrary, and based on its morphology, the Mesa Real Mt. must have been completely covered by the ice mass. The trough extends $8 \mathrm{~km}$ from the two 
flooded ones: Yendegaia at the $\mathrm{W}$ and Lapataia at the E. At this point, the Acigami paleo-glacier also joined from the NW to flow together to the $\mathrm{E}$ (Fig. 1c). The increase of the ice mass allowed the paleo-glacier system to develop a deeper part of the trough, which is known as Lapataia bay because it was flooded by marine waters after deglaciation (Rabassa et al. 1986, Rabassa et al. 2009). Moreover, marine deposits and macrofossils were found along the Acigami lake shore and along

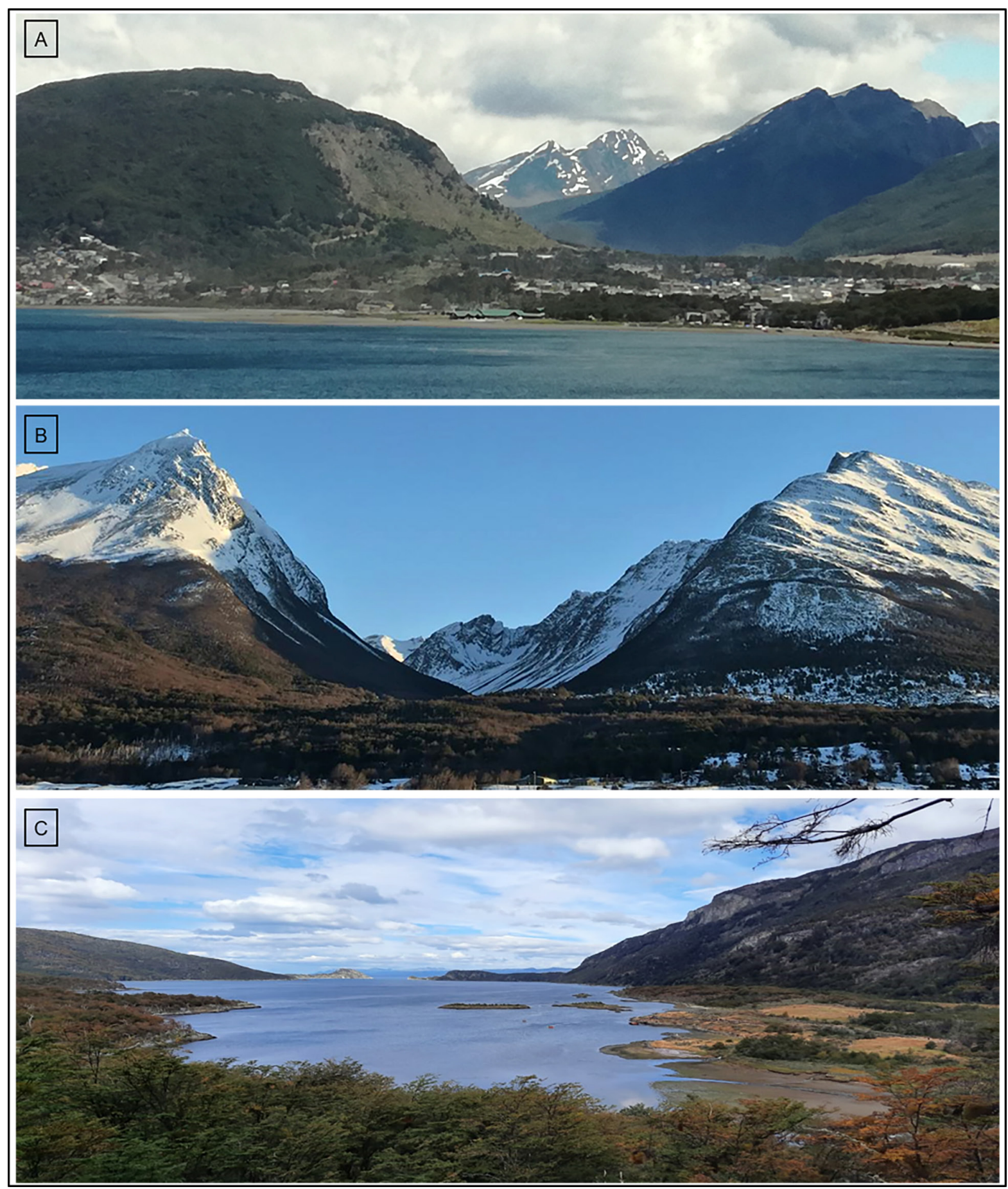

Fig. 11. Erosional landforms westwards Ushuaia city. A - Susana Mt. and Río Pipo trough (view to the W). Its rounded summit and stream-lined shape (500 $\mathrm{m}$ a.s.1.) show it was totally covered by ice while the other mountain summits were not, at its foot, basal moraines developed; B - Cañadón de la Oveja U-shaped, hanging valley joining the Río Pipo trough by a threshold, truncated spurs are visible in the right; $\mathrm{C}$ - view of the Lapataia trough to the E; at the back, its narrow entrance from the Beagle channel. 
the connecting terrain between it and the present shore; these findings contributed to reconstructing a Holocene paleo-fjord in the area (Gordillo et al. 1993). While the valley bottom in between the mountains has a maximum elevation of $80 \mathrm{~m}$ a.s.l., the deepest part of the flooded trough is $20 \mathrm{~m}$ b.s.l. A threshold $80 \mathrm{~m}$ deep located out of the bay communicates with the Beagle channel bottom. This geomorphological evolution enables us to postulate Lapataia bay as a pseudo-fjord whose headers do not exist. This erosional landscape resulted from the LGM when all the area was covered by an ice network, being the Beagle paleo-glacier accumulation area (Coronato 1995). Peaks $>1000 \mathrm{~m}$ a.s.l. were nunataks but the lowest mountains as Mesa Real, Bella Vista and Susana Mts. were totally covered by ice. The landform is included in the recreational zone of the Tierra del Fuego National Park being one of its most attractive resources. It is visited by thousands of persons every year by organised excursions or on their own. The end of NR3 is here, $3079 \mathrm{~km}$ south of its beginning in Buenos Aires city.

\section{L16. Drumlins $\left(54^{\circ} 52^{\prime} \mathrm{S}, 67^{\circ} 33^{\prime} \mathrm{W}\right.$, Figs $12 \mathrm{a}$ and $b$ )}

Depositional and erosional landforms with an inverted-spoon shape that show the direction of the ice flow. Drumlins typically appear in groups and are formed subglacially when the ice erodes its own deposits. These landforms correspond to the first drumlin field described in Argentina (Rabassa et al. 1990). The drumlins close to the Beagle channel shore have a W-E direction while the drumlins at the mountain foot have an NWSE direction. These different alignments indicate the existence of two paleo-glaciers involved in their formation: the Beagle and the Lasifashaj ones, respectively. The drumlin field extends also on Gable island, composed of 70 drumlins and five rocky drumlins, which are up to $2.5 \mathrm{~km}$ long, $0.3 \mathrm{~km}$ wide and up to $92 \mathrm{~m}$ a.s.l high. The internal structure is composed of a lower basal till unit, an ice-contact stratified-drift glaciofluvial unit, a glacio-lacustrine unit and a glacially reworked lacustro-till unit on top. The west-facing drumlins have strong sea wave erosion which generates a gable-like shape and gorges. The inter-drumlin depressions are occupied by mires, peat bogs and lagoons (Rabassa et al. 1988, Antonioni 2006). The drumlins inland are part of Harberton Ranch and can be visited after driving $40 \mathrm{~km}$ along RPJ which connects to NR3 about $35 \mathrm{~km}$ far from Ushuaia. There are maritime excursions that pass by the drumlins on the island though disembarking is not possible.

To sum up, these 16 glacial landforms are considered georesources, and most of them are easily

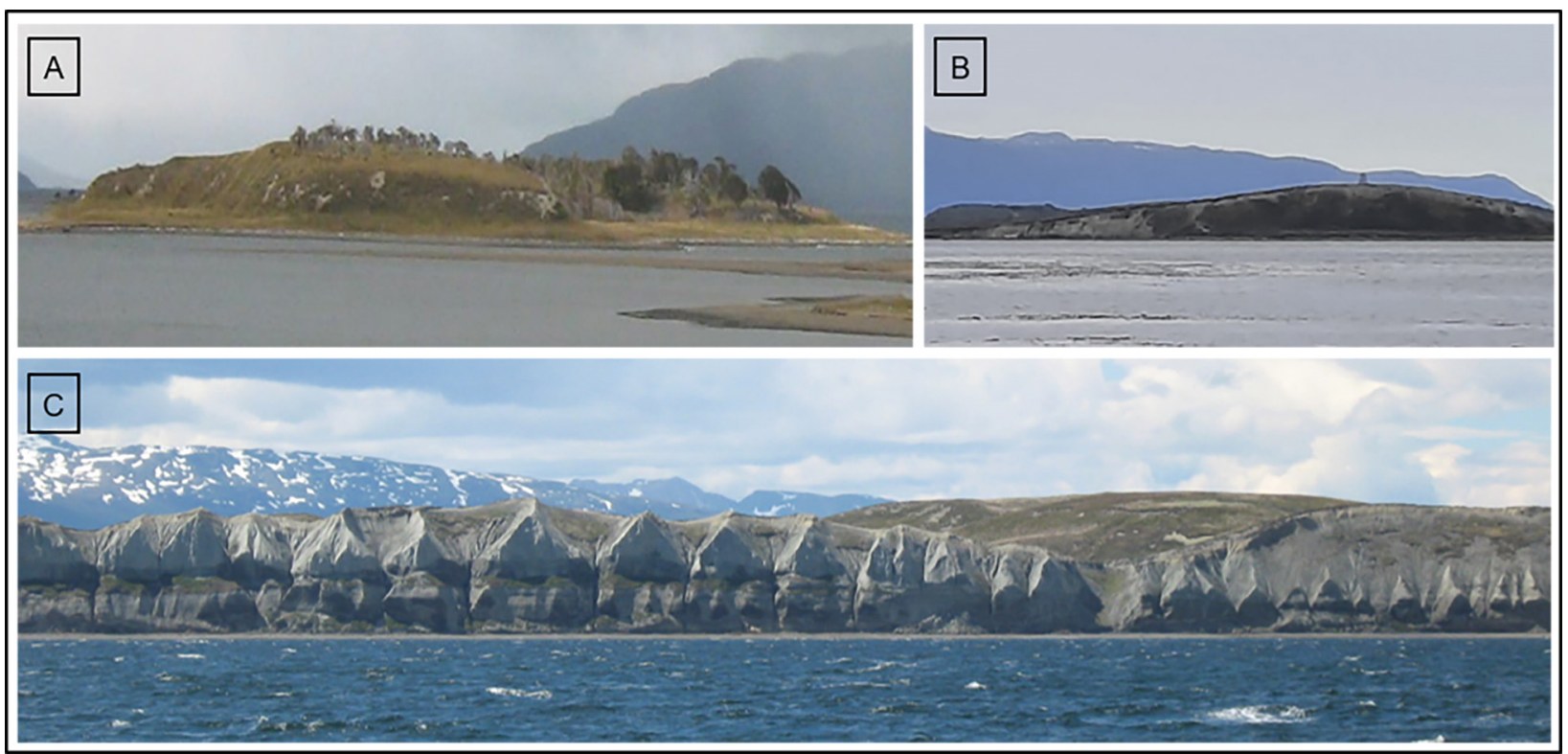

Fig. 12. Drumlins in the Beagle channel coasts. A and B - stream-lined depositional landforms in W-E direction; C - the Gable island wall formed by wave and runoff erosion at the western slope of drumlins, their internal composition can be seen by sailing or by binoculars from the coast. The name of the island refers to the architectural triangular shape, a very singular feature in the region. 
Table 2. Geodidactic functions of landforms regarding processes type and glacial chronology.

\begin{tabular}{|c|c|c|c|c|c|c|}
\hline $\begin{array}{l}\text { Geodidactic } \\
\text { functions }\end{array}$ & \multicolumn{3}{|c|}{$\begin{array}{l}\text { Regarding pro- } \\
\text { cesses }\end{array}$} & \multicolumn{3}{|c|}{$\begin{array}{l}\text { Regarding geo- } \\
\text { logical times }\end{array}$} \\
\hline Landforms & 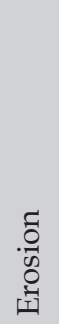 & 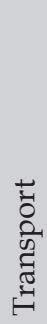 & 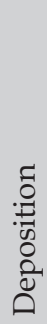 & 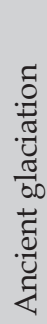 & 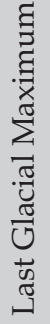 & 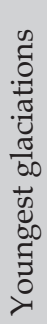 \\
\hline L1 & & & $x$ & $x$ & & \\
\hline L2 & $\times$ & $x$ & $x$ & $\times$ & & \\
\hline L3 & & & $x$ & $x$ & & \\
\hline L4 & & $x$ & $x$ & $x$ & & \\
\hline L5 & & & $x$ & & $x$ & \\
\hline L6 & & & $x$ & & $\times$ & \\
\hline L7 & $x$ & & $x$ & & $x$ & \\
\hline L8 & $\times$ & & & & $x$ & \\
\hline L9 & $x$ & & $\times$ & & $x$ & \\
\hline L10 & $\times$ & & & & $x$ & \\
\hline L11 & $\times$ & $\times$ & $\times$ & & $\times$ & $\times$ \\
\hline L12 & $x$ & & $\times$ & & $\times$ & \\
\hline L13 & $\times$ & & & & $x$ & \\
\hline L14 & $\times$ & & $\times$ & & $\times$ & \\
\hline L15 & $\times$ & & & & $\times$ & \\
\hline L16 & $\times$ & & $x$ & & $x$ & \\
\hline
\end{tabular}

observed from roads. A few of them are in public reserves with different access conditions, others are on private lands and the access is not free. According to their location, they can be visited and appreciated by driving, hiking, horse-riding and sailing, considering the corresponding regulations. Table 2 shows every landform classified according to the didactic potential they offer as regards glacial processes and time.

\section{Discussion}

The16landforms selected and described as georesources represent a sample of glacial landforms with attractiveness and potential to be considered as geomorphosites for geotourism purposes. By the way, the Beagle channel, the longest trough, later flooded by sea waters, has been declared as one of the 75 Argentinean geological interest sites (Sitio de Interés Geológico), being the first and the only one selected for Tierra del Fuego (Bujalesky et al. 2008). However, the rest of the georesources presented represent ancient glaciations, the
LGM and the youngest glaciations. According to Jamorska et al. (2020), the features of the old glacial landscape together with the features of the young glacial landscape can be defined as potential geosites. This may be reasonable enough to consider enlarging the list of geological interest sites in the country. This kind of landscape is useful to teach that climatic variability has occurred several times on the planet by natural, external forces before the atmosphere became polluted and the present climate warming triggers. The glacial history of Tierra del Fuego is thoroughly documented in several papers (Caldenius 1932, Rabassa et al., 2000, Coronato et al. 2004a, Rabassa 2008, Rutter et al. 2012, among others).

In addition, Piacentini et al. (2011) described examples of glacial landforms in Italy at different spatial (from regional to local) and temporal (from Trias to Holocene and present) scales. By the same token, the 16 georesources analysed show a spatial scale that includes the Andean mountains and the northern low ranges and plains areas; as to the temporal scale, they show three moments: middle and late Pleistocene, Holocene and recent centuries. This could stimulate the development of people's sensitivity to read in the landscape long-term temporal scales processes, that lead to the present landscape of a region (Piacentini et al. 2011: 257). Besides, $50 \%$ of the georesources have 2 geodidactic functions, while $31.25 \%$ have 3 and $18.75 \%$ have 4 or 5 .

All these facts show why these 16 landforms are geodiversity resources that have a high geodidactic potential that could be promoted if a geotourism strategy was accomplished in the region. By means of such an enterprise, visitors and locals could learn about global climate changes throughout the history of the Southern Hemisphere, how glaciers are formed, the power they have to model the landscape by eroding and depositing new landforms, how the sea level changes when the water cycle is interrupted because water remains in continents as ice, the influence solar activity has in our planet and why cold periods are followed by warmer ones. Consequently, people could embrace a better understanding of natural processes.

\section{Final comments}

Glacial landforms located in the present non-glaciated landscape, as most of the described 
here, have a unique possibility to show the impact of natural climatic changes on glacier expansion and relief sculpture as well as their capacity and competence as geomorphic agents. Thus, the list could be enlarged using other criteria rather than the authors' experiences both in geomorphology and tourism. The datasheet designed to collect information turned out to be a useful tool for fieldwork and it may be used in some other geographical areas. Because of these reasons, these 16 landforms have a great value as regards their scientific properties, such as representativeness and singularity, as well as their geodidactic potential. Moreover, they could be part of a geoconservation policy by declaring them as geosites or geomorphosites devoted to science and education, including geotourism. Nevertheless, the private property, where many of these georesources are located, and the different land-use types given to them (i.e. farming, mining, oil extraction and forestry) may not be completely compatible with leisure or available for conservation. Despite this, most of the landforms selected are observable from the main paved road that crosses the region. Using the glacial landscape for a better understanding of natural processes that refer to the last one million years may be of great utility to disclose, take care and preserve a significant part of the local geodiversity.

\section{Acknowledgements}

The authors thank Zbigniew Zwolinski for his kind invitation to publish the essence of an online presentation given in a webinar about Tierra del Fuego as a scenery for geoconservation organised by Universidad Nacional de Tierra del Fuego, Ushuaia, in December 2020. Several colleagues, students and sponsor institutions collaborated to perform different research projects from which most of the presented results were obtained and published in the mentioned papers. R. López (CADIC-CONICET) helped with figures design. To Jorge Rabassa (CADIC-CONICET, retired) who initiated and promoted glacial research in Tierra del Fuego.

\section{Author's contribution}

A. Coronato (40\%): conceptualisation, investigation, visualisation, writing (draft and review).
S. Schwarz (40\%): conceptualisation, methodology, visualisation, figure design and elaboration, writing (draft and review). F. Flores Barrera (20\%): visualisation, figure design and elaboration, writing (draft).

\section{References}

Antonioni G., 2006. Génesis de drumlins del Pleistoceno Tardío y análisis geomorfológico de la Estancia Harberton (Tierra del Fuego, Argentina). Phd Dissertation. Università degli studi di Trieste, Trieste. Unpublished.

Bouzekraoui H., Barakat A., Touhami F., Mouaddine A., El Youssi M., 2017. Inventory and assessment of geomorphosites for geotourism development: A case study of Ait Bou Oulli valley (Central High-Atlas, Morocco). Area 50(3): 331-343. DOI 10.1111/area.12380.

Bruschi V.M., 2007. Desarrollo de una metodología para la caracterización, evaluación y gestión de los recursos de la geodiversidad. Phd Dissertation. Universidad de Cantabria, Santander. Unpublished. Online: https://repositorio. unican.es/xmlui/handle/10902/1291 (accessed 19 March 2021).

Bujalesky G.G., Coronato A.M., Rabassa J.O., Acevedo R.D., 2008. El Canal Beagle. Un ambiente esculpido por el hielo. In: CSIGA (ed.). Sitios de Interés Geológico de la República Argentina. Los geólogos nos cuentan. Anales 46 (II), Buenos Aires: 849-864.

Bujalesky G.G., Heusser C.J., Coronato A.M., Roig C.E., Rabassa J.O., 1997. Pleistocene glaciolacustrine sedimentation at Lago Fagnano, Andes of Tierra del Fuego, Southernmost South America. Quaternary Science Reviews 16(7): 767-778. DOI 10.1016/S0277-3791(97)00018-8.

Caldenius C.C., 1932. Las Glaciaciones Cuaternarias en Patagonia y Tierra del Fuego. Ministerio de Agricultura de la Nación. Dirección General de Minas y Geología. 95: 1-148. Buenos Aires. DOI 10.2307/519583.

Cohen C., Schwarz S., Facen M., Flores F., González S., López H., Quidulef A., Vera J.R., 2020. El uso de sistemas de información geográfica en la identificación y valoración de recursos geoturísticos. Informes Cientificos Tecnicos-UNPA 12(4): 32-44. DOI 10.22305/ict-unpa.v12. n4.752.

Coronato A., 1993. La glaciación Moat (Pleistoceno Superior) en los valles Pipo y Cañadón del Toro, Andes Fueguinos. Actas del XII Congreso Geológico Argentino, Mendoza VI. 6: 40-47.

Coronato A., 1995. The last Pleistocene Glaciation in tributary valleys of the Beagle Channel, Southernmost South America. Quaternary of South America and Antarctic Peninsula 9: 173-182.

Coronato A., Meglioli A., Rabassa J., 2004a. Glaciations in the Magellan Straits and Tierra del Fuego, Southernmost South America. In: Ehlers J., Gibbard P., (eds.) Quaternary Glaciations - Extent and Chronology. Part III. Elsevier, Quaternary Book Series 15: 45-48. DOI 10.1016/ S1571-0866(04)80110-6.

Coronato A., Martínez O., Rabassa J., 2004b. Pleistocene Glaciations in Argentine Patagonia, South America. In: Ehlers J., Gibbard P., (eds), Quaternary Glaciations - Extent and Chronology. Part III. Elsevier, Quaternary Book Series 15: 49-67. DOI 10.1016/S1571-0866(04)80111-8. 
Coronato A., Mazzoni E., Vázquez M., Coronato F.R., 2017. Patagonia. Una síntesis de su Geografía Física. Editorial UNPA, Río Gallegos.

Coronato A.M., Coronato F., Mazzoni E., Vázquez M., 2008a. Physical Geography of Patagonia and Tierra del Fuego. Development in Quaternary Sciences 11: 13-56. DOI 10.1016/S1571-0866(07)10003-8.

Coronato A., Ponce F., Sepälä M., Rabassa J., Zappettini E., Crosta S., Gonzalez M.A., Segal S., 2008b. Englazamiento del valle del río Fuego durante el Pleistoceno tardío, Tierra del Fuego, Argentina. Actas del XVII Congreso Geológico Argentino: 1194-1195.

Coronato A., Rabassa J., 2011. Pleistocene Glaciations in Southern Patagonia and Tierra del Fuego. Development in Quaternary Sciences 15: 715-727. DOI 10.1016/B978-0444-53447-7.00051-9.

Coronato A., Seppälä M., Ponce J.F., Rabassa J., 2009. Glacial geomorphology of the Pleistocene Lake Fagnano ice lobe, Tierra del Fuego, southern South America. Geomorphology 112(1-2): 67-81. DOI 10.1016/j.geomorph.2009.05.005.

Darvill C.M., Bentley M.J., Stockes C.R., 2015. Geomorphology and weathering characteristics of erratic boulder trains on Tierra del Fuego, southernmost South America: Implications for dating of glacial deposits. Geomorphology 228: 382-397. DOI 10.1016/j.geomorph.2014.09.017.

Díaz Balocchi L., Ponce J. F., Tripaldi A., Magneres I., 2018. Asociaciones de geoformas y depósitos del sector norte del lóbulo Bahía Inútil-Bahía San Sebastián, Tierra del Fuego. In: Bouza P., Veiga G., Piovano E., Zárate M., Bilmes A. (eds.), Proceedings of the 7th Argentinian Congress on Quaternary and Geomorphology: 206-207.

Díaz Balocchi L., Ponce J.F., Tripaldi A., Magneres I., 2020. Geomorphology of the northeastern extreme of Isla Grande de Tierra del Fuego, Argentina, Journal of Maps 16(2): 512-523. DOI 10.1080/17445647.2020.1780168.

Diolaiuti G., Smiraglia C., 2010. Changing glaciers in a changing climate: How vanishing geomorphosites have been driving deep changes in mountain landscapes and environments. Géomorphologie 16(2): 131-152. DOI 10.4000/ geomorphologie.7882.

Dixon G., 1996. Geoconservation: An international review and strategy for Tasmania. Parks and Wildlife Service, Tasmania.

Dowling R., Newsome D., 2018. Handbook of geotourism. Edward Elgar Publishing. DOI 10.4337/9781785368868.

Durán J.J., 1999. El patrimonio geológico de España: situación actual y perspectivas de futuro. In: Mata Perelló J., Serra J. (eds.). I Simposio Transfronterizo sobre Patrimonio Natural, Lleida: 7-20.

Flores F., 2020. Geoturismo urbano: una propuesta para diversificar la oferta turístico- recreativa en Ushuaia. Bachelor degree dissertation. Universidad Nacional de Tierra del Fuego, Antártida e Islas del Atlántico Sur, Ushuaia. Unpublished.

Gordillo S., Coronato A., Rabassa J., 1993. Late Quaternary evolution of a Subantarctic paleofjord, Tierra del Fuego. Quaternary Science Reviews 12(10): 889-912. DOI 10.1016/0277-3791(93)90027-J.

Gray M., 2004. Geodiversity. Valuing and conserving abiotic nature. John Wiley \& Sons, West Sussex.

Gray M., 2005. Geodiversity and geoconservation: what, why and how? The George Wright Forum 22: 4-12.

Hose T., 1995. Selling the story of Britain's Stone. Environmental interpretation 10(2): 16-17.

IPIEC, 2021. Proyecciones y estimaciones de población de Tierra del Fuego. Online: https://ipiec.tierradelfuego. gov.ar/serie-analisis-demografico/(accessed 29 March 2021).

Isla F., Schnack E., 1995. Submerged moraines offshore Tierra del Fuego, Argentina. Quaternary of South America and Antarctic Peninsula 9: 205-222.

Jamorska I., Sobiech M., Karasiewicz T., Tylmann K. 2020. Geoheritage of Postglacial Areas in Northern Poland-Prospects for Geotourism. Geoheritage 12(12). DOI 10.1007/s12371-020-00431-0.

Kaplan M., Coronato A., Hulton N., Rabassa J., Stone J., Kubik P., 2007. Cosmogenic nuclide measurements in southernmost South America and implications for landscape change. Geomorphology 87: 284-231. DOI 10.1016/j. geomorph.2006.10.005.

McCulloch R., Fogwill C., Sudgen D., Bentley M., Kubik P., 2005. Chronology of the Last Glaciation in Central Strait of Magellan and Bahía Inútil, Southernmost South America. Geografiska Annaler 87A(2): 289-312. DOI j.04353676.2005.00260.x.

Meglioli A., 1992. Glacial Geology of Southernmost Patagonia, the Strait of Magellan and Northern Tierra del Fuego. Ph.D. Dissertation, Lehigh University, Bethlehem. Unpublished.

Migoń P., 2018. Geoheritage and World Heritage Sites. In: Reynard E., Brilhá J. (eds.). Geoheritage. Elsevier, Netherlands: 237-249. DOI 10.1016/B978-0-12-809531-7.00013-7.

Millán Escriche M., 2011. La función didáctica del geoturismo. Propuestas para la región de Murcia. Journal of Tourism Research Gran Tour 4: 62-93.

Nieto L., 2001. Geodiversidad: propuesta de una definición integradora. Boletín Geológico y Minero 112(2): 3-12.

Ollier C., (2012) Problems of geotourism and geodiversity. Quaestiones Geographicae 31(3): 57-61. DOI 10.2478/ v10117-012-0025-5.

Piacentini T., Castaldini D., Coratza P., Farabollini P., Miccadei E., 2011. Geoturism: some examples in northern-central Italy. GeoJournal of Tourism and Geosites 4-2(8): 240262.

Planas X., Ponsa A, Coronato A., Rabassa J., 2002. Geomorphological features of Late Glacial-Holocene Glaciations in Martial Cirque, Fuegian Andes, Southernmost South America. Quaternary International 87(1): 19-27. DOI 10.1016/S1040-6182(01)00059-3.

Quesada-Román A., Pérez-Umaña D., 2020. Tropical Paleoglacial Geoheritage Inventory for Geotourism Management of Chirripó National Park, Costa Rica. Geoheritage 12(58). DOI 10.1007/s12371-020-00485-0.

Rabassa J., 2008. Late Cenozoic Glaciations in Patagonia and Tierra del Fuego. In: Rabassa J. (ed.) Late Cenozoic of Patagonia and Tierra del Fuego. Elsevier, Development in Quaternary Sciences 11(3): 151-204. DOI 10.1016/S15710866(07)10008-7.

Rabassa J., Coronato A., Bujalesky G., Salemme M., Roig C., Meglioli A., Heusser C., Gordillo S., Roig F., Borromei A., Quattrocchio M., 2000. Quaternary of Tierra del Fuego, southernmost South America: an updated review. Quaternary International 68-71: 217-240. DOI 10.1016/S10406182(00)00046-X.

Rabassa J., Coronato A., Gordillo S., Candel M.S., Martínez M.A., 2009. Paleoambientes litorales durante la Transgresión Marina Holocena en Bahía Lapataia, Canal Beagle, Parque Nacional Tierra del Fuego, Argentina. Revista de la Asociación Geológica Argentina 65(4): 648-659.

Rabassa J., Heusser C., Stuckenrath R., 1986. New Data on Holocene Sea Transgression in the Beagle Channel: Tierra del Fuego, Argentina. Quaternary of South 
America and Antarctic Peninsula 4: 291-309. DOI 10.1201/9781003079316-15.

Rabassa J., Serrat D., Martí C., Coronato A., 1988. Estructura Interna de Drumlins, Isla Gable, Tierra del Fuego, Argentina. II Reunión Argentina de Sedimentología. Asociación Sedimentológica Argentina, Buenos Aires.

Rabassa J., Serrat D., Martí C., Coronato A., 1990. Internal Structure of drumlins of Tierra del Fuego in Gable Island, Beagle Channel, Tierra del Fuego, Argentina. LUNDQUA Report 32: 3-5.

Reynard E., 2004. Geosites. In: Goudie A. (ed). Encyclopedia of Geomorphology. Routledge, London.

Roig F., 1998. La Vegetación de la Patagonia. In: Correa M. (ed.). Flora Patagónica. INTA, Buenos Aires, I: 48-167.

Rutter N., Coronato A., Helmens K., Rabassa J., Zarate M., 2012. Glaciations in North and South America from the Miocene to the Last Glacial Maximum: comparisons, linkages, and uncertainties. Springer Briefs in Earth Sciences. Springer Sciences+Business Media. DOI 10.1007/978-94-007-43991.

Sadry B., 2009. Fundamentals of geotourism: with emphasis on Iran. Samt Organization Publishing, Tehran.

Serrano Cañadas E., Ruiz Flaño P., 2007. Geodiversidad: concepto, evaluación y aplicación territorial. Boletín de la Asociación de Geógrafos Españoles 45: 79-98.

Schwarz S., 2013. Propuesta de circuito geoturístico en el sector Sur de Tierra del Fuego. Actas I Simposio Argentino de Patrimonio Geológico, Geoparques y Geoturismo. III Encuentro Latinoamericano de Geoparques. UNESCO-SEGEMAR, San Martín de los Andes: 55-56.

Schwarz S., 2017. Geoturismo en el paisaje estepario de Tierra del Fuego (Argentina): repensando su atractividad. PASOS 15(1): 105-119. DOI 10.25145/j.pasos.2017.15.007.
Schwarz S., 2019. Geodiversidad en el centro y norte de Tierra del Fuego: recursos para un potencial desarrollo geoturístico. Phd Dissertation. Universidad Nacional de La Plata, La Plata. Unpublished. Online: http://www.memoria.fahce. unlp.edu.ar/tesis/te.1696/te.1696.pdf (accessed 12 April 2021).

Schwarz S., Coronato A., 2019. Assessing geodiversity in Tierra del Fuego (Southern Patagonia, Argentina). A strategy to promote geotourism. IAG-Regional Conference on Geomorphology. International Association of Geomorphologists, Athens: 262.

Schwarz S., Coronato A., Rabassa J., 2014. El campo de bloques erráticos de Punta Sinaí, Tierra del Fuego: potencial sitio de interés geológico. Actas del XIX Congreso Geológico Argentino. Asociación Geológica Argentina, Córdoba: 578-579.

Schwarz S., Migoń P., 2017. When science and leisure meet: a geotourist itinerary in Southern Tierra del Fuego, Argentina. In: Rabassa J. (ed.), Advances in geomorphology and Quaternary studies in Argentina. Earth System Sciences. Springer: 49-75. DOI 10.1007/978-3-319-54371-0_2.

Walther A., Rabassa J., Coronato A., Tassone A., Vilas J. F., 2007. Paleomagnetic study of glacigenic sediments from Tierra del Fuego. Geosur 2007 Abstract volume: 174.

Zwoliński Z., 2009. The routine of landform geodiversity map design for the Polish Carpathian Mts. Landform Analysis 11: 77-85.

Zwoliński Z., Stachowiak J., 2012. Geodiversity map of the Tatra National Park for geotourism. Quaestiones Geographicae 31(1): 99-107. DOI 10.2478/v10117-012-0012-x. 